\title{
Evolving Patterns of Payment Methods in Turkish Foreign Trade
}

\author{
Kemal Türkcan ${ }^{1}$ \\ Received: 16/01/2016; Revised: 22/05/2016; Accepted: 19/06/2016
}

\begin{abstract}
Serving the global marketplace brings many risks to the firms that they may not have on the domestic side. Apart from financing, trade finance mechanisms assist exporters and importers to mitigate or reduce their risks associated with doing business internationally. The present paper sheds lights on the structure and evaluation of payment methods in international trade as well as their changing composition due to 2008-2009 global financial crisis using a unique bilateral trade finance data from Turkey with 206 countries over the period 2002-2012 at the 2digit level of ISIC Revision 3. Three key results emerge. First, Turkey's exports are mainly financed via open account method while the majority of its imports were executed via cash-in advance method. Second, the shares of inter-firm trade finance (open account and cash-in advance) in Turkey's foreign trade dramatically increased over the period 2002-2012, while the shares of the intermediate trade finance (cash against documents and letter of credit) decreased substantially. Finally, the evidence show that both exporters and importers started to use cashin advance method, the safest method of payment, more intensively than other methods shortly after the global recession in 2008. Overall, the patterns presented in this paper highlight the fact that Turkish traders are not able to set payment terms that are highly favorable to themselves and bear all risks associated with international trade transactions.
\end{abstract}

Keywords: Method of payments; Trade finance; Trade credit; Financial crisis; Turkey

JEL Codes: F12, F13, F34, G21, G32

\footnotetext{
${ }^{1}$ Department of Economics, Akdeniz University, Antalya, Turkey. e-mail: kturkcan@akdeniz.edu.tr
} 


\section{Introduction}

As a result of trade liberalization measures and market-economic reforms in the mid-1980s, Turkey's economy grew significantly over the past three decades-one of the best-performing emerging economies in the world (Gros and Selçuki, 2013). From 2002 to 2008, in particular, Turkey's economy grew by an average of $5.91 \%$ per year. The same period witnessed substantial increase in trade as well. Between 2002 and 2008, total merchandise trade volumes rose by $24.5 \%$ annually-well above the world average. ${ }^{2}$ Many factors contribute to economic growth, and although some factors are more important than others, there is an extensive body of theoretical and empirical research concluded that trade has been major factor responsible for economic growth in developing and transition economies, including Turkey. The steady growth of international trade has also enabled Turkey to become fully integrated into the global economy (Kaminski and Ng, 2006).

After a period of steady growth from 2002 to 2008, Turkish economy contracted by $4.82 \%$ in 2009 as a result of the global financial crisis that started in the United States in the late 2008 and quickly spread to Europe and other economies around the world. ${ }^{3}$ Triggered by a collapse of import demand in major developed countries and the meltdown in trade credit, trade flows of Turkey fell dramatically by $27.2 \%$ in $2009 .{ }^{4}$

However, Turkish economy recovered fairly rapidly from the recent financial crisis thanks to the strong domestic demand (Kalkan and Cünedioğlu, 2010). After a sharp contraction in 2009, the economy rebounded quickly with an annual average growth rate of $6.7 \%$ over the period 2010-2012, well above the pre-crisis average rate of 5.9\% (2002-2008). On the other hand, Turkish trade flows, particularly exports, recovered slowly from the adverse effects of the financial crisis and achieved a growth rate below its pre-crisis average (17.4\%) in the next three years. Despite the gradual post-crisis recovery, it is striking that Turkish trade flows are still below potential mainly due to the sluggish demand in the traditional markets, particularly in Europe ${ }^{5}$, as well as the increase in the cost of trade finance (Acar, 2009 and Malueche, 2009a).

Trade finance is a critical component of the global economy. More than $90 \%$ of cross border transactions are facilitated by some form of trade finance, including every kind of loan, insurance policy or guarantee, especially short-term (Auboin, 2007). ${ }^{6}$ Trade finance is essential to keep international trade running smoothly, as was clearly demonstrated when the global credit crunch magnified the slowdown in exports following the financial crisis in 2008-2009. ${ }^{7}$ In the wake of the global financial crisis, many researchers have drawn attention to the structure and recent evolution of the global trade finance market, and the link between financial conditions and international trade especially during the 2008-2009 financial crisis (including, but not limited to Malouche, 2009a; Asmundson et al., 2011; Mora and Powers, 2011; Amiti and Weinstein, 2011; Chor and Manova, 2012; Manova, 2013; and Love, 2013).

\footnotetext{
2 Annual growth rates of Gross Domestic Product (GDP) and merchandise trade flows are derived from the World Bank's World Development Indicators database (WDI): http://data.worldbank.org/indicator.

${ }^{3}$ Malueche (2009a) suggest that the impact of the decline has been relatively severe in countries including Turkey, that are integrated and dependent on trade with developed countries.

${ }^{4}$ Malueche (2009a) find that value of letters of credit issued by the Turkish banking sector declined by $25 \%$ between September and December 2008 while export credits provided by the Turkish banking sector decreased by $13 \%$ during the same period.

5 Türkcan (2014).

${ }^{6}$ However, as pointed by Love (2013), this estimate was based on a questionable data, especially bank-level surveys.

${ }^{7}$ The number of SWIFT (Society for Worldwide Interbank Financial Telecommunication) messages dropped from 46 million 2008 to 42 million in 2009 as world trade has been fell in volume terms by around 12\%, according to the World Trade Organization (WTO) (ICC, 2010).
} 
Trade finance is broadly defined as the methods and instruments designed to support exporters and importers throughout the trade cycle (Menichini, 2009). Firms serving the international market may use a wide array of trade finance instruments depending on the degree of trust between the trading partners. Traditionally, commercial banks, private insurers, export credit agencies, multilateral development banks, suppliers and buyers provide trade finance. Trade finance generally involves short-term financing to facilitate export and import transactions. Typical trade-related finance methods and instruments available include working capital credit, pre-export finance, letter of credit, supplier credit, buyer credit, countertrade, factoring and forfeiting, advance payment guarantees, hedging, export credit insurance and export credit guarantees, etc. ${ }^{8}$ Regardless of the term involved, trade finance performs four basic functions in facilitating international transactions: financing, risk mitigation, payment facilitation, and the provision of information about the status of payments or shipment (ITC, 2009).

Trade finance mechanisms provide the necessary capital and liquidity to exporters before sending shipment (pre-shipment financing) and after the shipment (post-shipment financing). The pre-shipment financing is designed to support pre-export activities (such as wages, the purchase of inventory, raw materials or the manufacture of a product) and while the post-shipment financing is designed to support post-export activities (such as collection of the international receivables generated from open account transactions). ${ }^{9}$ Trade finance mechanisms also provide the capital to buyers or importers to finance their imports of commodities, capital goods and manufactured goods.

Apart from financing, trade finance mechanisms assist help exporters and importers to mitigate or reduce their risks associated with doing business internationally. Serving the global marketplace brings many risks to the firms that they may not have on the domestic side. The risks associated with international transactions are exchange rate fluctuations, conflict and political unrests, default risk or payment delay risk, asymmetric information risk, supply chain risk, financial intermediary risk, liquidity risk, among others (Love, 2013).

Finally, trade finance offers a range of payment mechanisms that enable exporters to obtain secure and timely payment from importers while enabling the importers to obtain the shipment of goods as stated in the contract. Since getting paid in full and on time for the exporter and receiving the goods as stated for the importer is the most important point in any form of trade, an acceptable method of payment must be agreed between exporter and importer to minimize the default and non-delivery risks. Generally, there are four common methods of payment for international transactions: Open account (OA), cash-in advance (CIA), letter of credit (L/C) and cash against documents (CAD). As illustrated in more detail in Table A1, each of the four payment methods has different risk levels and provides a different level of protection to exporters and importers. For example, CIA is considered to the most secure and the least risky method of international trading from the exporter's point of view as the exporters receive the payment before the delivery. For importers, however, CIA is the most risky payment system. In contrast, OA is the most attractive to the importer because in an OA sale, the shipment takes place before the payment is due.

Between these two extremes, banks offer L/C or CAD to prevent the risk of default and non-delivery between the exporter and importer, provided that all terms and conditions as

\footnotetext{
${ }^{8}$ For detailed lists of all available trade finance methods and instruments, see Chauffour and Farole (2009).

${ }^{9}$ In addition to the aforementioned activities, exporters carry out numerous export activities when selling across international borders, which in turn force firms to seek external funds. These activities include learning about the profitability of new export markets, making market-specific investments in capacity, product customization, and regulatory compliance, setting up and maintaining foreign distribution networks. Moreover, exporters tend to be more reliant on external financing than domestic producers because of additional variable costs, such as transportation costs, duties, and insurance (Contessi and Nicola, 2012).
} 
specified in the L/C or CAD have been fully met (Love, 2013). L/C is one of the most widely used $^{10}$, versatile and secure method of payment for goods in international transactions. An L/C is a financial instrument issued by a bank at the request of its customer (the importer) that payment will made to the exporter, provided that all shipping documents stated in the $\mathrm{L} / \mathrm{C}$ are submitted to the issuing bank (importer's bank) by the confirming bank (exporter's bank) and the terms and conditions set out in the L/C are fully met. The L/C also provides security for the importer since the payment will be made by the issuing bank upon receipt of the documents confirming shipment of the goods as agreed. While an $\mathrm{L} / \mathrm{C}$ is secure method of payment for goods in international transactions, it is the most expensive form of payment. A simple and cheaper alternative to the $\mathrm{L} / \mathrm{C}$ is $\mathrm{CAD}$, where the exporter presents the shipping documents to his bank (remitting bank), which in turn sends them to the importer's bank (collecting bank), along with instructions for payment. Payments are received from the importer and remitted to the exporter through the banks in exchange for those documents (ITA, 2012).

Although trade finance performs a wide range of functions in facilitating international transactions, this paper primarily focuses on the payment aspect of trade finance, with particular emphasis on the evaluations of payment choice during the global financial crisis. As emphasized by Auboin and Engemann (2013), the focus on the payment contract choice in international trade is a novel approach to understanding the structure and functioning of the trade finance market because that understanding can help policy-makers to take appropriate policy actions and measures in a timely fashion to mitigate the impact of the financial crisis on the trade finance markets.

While the literature convincingly points out the importance of the essential linkages between trade finance and trade flows, the research on the choice of the payment method in trade flows, especially based on actual country-level trade finance data, remains limited. Previous analyses are either based on firm-level data (such as Hoefele et al., 2013, Antras and Foley, 2013) or bank-level data (Asmundson et al., 2011 and BIS, 2014) or both (Malouche, $2009 \mathrm{~b}$ ). The firm-level data and bank-level data, mainly collected through firm-level and banklevel surveys, provide extremely valuable information for understanding the structure and functioning of the trade finance market around the world. However, these surveys, particularly bank-level surveys, should be treated with great caution due to the insufficient coverage of inter-firm transactions and lack of uniformity in coverage across different surveys (Love, 2013). Moreover, these surveys do not provide detailed information on the usage of different types of payment methods on a bilateral basis, which in turn hampers the investigation of the structure and evaluation of trade financing by trading partners. Very few countries (e.g. Turkey, Brazil, India, Italy and Korea) provide sufficient country-level trade finance data on a bilateral basis covering the whole economy (inter-firm transactions plus intermediated trade finance) (Malouche, 2009b and BIS, 2014).

Turkey, especially considering the post-2000 period, is particularly useful starting point for our investigation. First, Turkey is one the few countries publishing detailed actual trade data on payment methods in trade transactions, making it easier to analyze the use of financing terms in Turkey's trade across income groups, regions and industry groups. Second, Turkey's foreign trade, in respect of both exports and imports, has grown remarkably from 2002 to 2012 and notable changes in the structure of exports have been observed (Türkcan, 2014). With respect to the extensive margin, the Exporter Dynamics Database of the World Bank shows that the number of exporting firms increased from 30,000 to 48,000 and the number of exporters per export destination increased from 500 to 1000 between 2002 and 2010. ${ }^{11}$ The number of export markets with an export volume over 1 billion USD increased from 5 in 2000 to more than 30

\footnotetext{
${ }^{10}$ Some estimates report that about $15 \%$ of global trade in 2011 is facilitated by the L/C (BIS, 2014).

${ }^{11}$ For instance, Aldan and Çulha (2013) and Türkcan (2014) provided evidence that Turkey has successfully diversified its exports by products and destination markets during recent years.
} 
in 2010. ${ }^{12}$ In addition to all these points, share of top 10 markets in Turkey's total exports decreased from $62 \%$ in 2000 to $48 \%$ in 2010. Overall, Turkey is a suitable country for the analysis on types of trade finance not only because of the disaggregated data on types of trade finance but also because of the increase in its ties with global production networks and the pattern of diversification in its exports over the period of our sample. ${ }^{13}$

Hence, given the growing role of trade financing in trade flows and a lack of good quantitative evidence ${ }^{14}$, this paper aims to fill this gap in the literature by investigating the structure and evaluation of trade financing across income groups and regions using a unique bilateral trade finance data from Turkey with 206 countries over the period 2002-2012 at the 2digit level of ISIC Revision 3. Further, for the purposes of this paper, the present paper attempts to document the changes in shares of methods of payments due to the 2008-2009 crisis.

The rest of the paper is organized as follows. Section 2 reviews the theoretical and empirical work related to trade finance, followed by a structural description of the dataset employed in the analysis (Section 3). Section 4 presents key findings and trends on the usage of different types of payment methods in Turkey across income groups, regions as well as product groups while Section 5 evaluates the impact of the 2008-2009 financial crisis on trade finance usage in Turkey. A final section gives concluding remarks as well as policy recommendations.

\section{A Review of the Theoretical and Empirical Literature on Trade Finance}

The 2008-2009 financial crisis prompted a renewed interest among economists to examine the links between financial conditions and trade flows. Many of these studies in this area have largely focused on the role of trade finance in the 2008-2009 great trade collapse. ${ }^{15}$ Many studies suggested that contraction in trade finance was not main driver behind the 2008-2009 trade collapse; rather, the collapse of aggregate demand and the decline in commodity prices were the leading causes of the sharp decline in trade (See Bricongne et al., 2012 and Behrens et al., 2013). In contrast, a number of studies, including Amiti and Weinstein (2011) and Chor and Manova (2012), found that trade finance constraints played a contributing role in the collapse of trade. Despite the lack of evidential consensus on the role of the trade finance on trade collapse, there is a little doubt that trade finance plays a significant role in facilitation of global commerce.

Unfortunately, these studies, with few exceptions, neglect one of the most important aspects of the trade finance, namely the payment contract choice of firms and their implications for trade. Attempts to understand the choice between different payment methods may provide useful information to policymakers in formulating effective and timely measures in times of crisis. Emphasized by Auboin and Engemann (2013) and Love (2013), the scarcity of reliable and comprehensive database was the main reason for the shortage of theory based-empirical research on the choice of trade finance methods. A notable exception is Schmidt-Eisenlohr (2013) who derives a theoretical model to address the trade-off firms have between three

\footnotetext{
12 These are approximate numbers.

13 Turkey's spectacular export performance over the years is mainly driven by the increasing participation of Turkish companies into the global value chains in recent years (Kaminski and Ng, 2006; Sayg1lı and Sayg1lı, 2011; and Gros and Selçuki, 2013).

${ }^{14}$ Notable exceptions are Acar (2009), Malouche (2009b), Kalkan et al. (2010), Demir and Javorcik (2014) and Demir (2014), which provide brief information about trade financing in Turkey by types of payments. Compared to these papers, the present paper provide a more detailed description on the usage of different types of payment methods in Turkey across income groups and regions. The present paper, unlike the papers just cited, also provides additional evidence on the use of financing terms in Turkey's trade before and after the financial crisis.

${ }^{15}$ See, for example, Iacovone and Zavacka (2009), Levchenko et al. (2010), Amiti and Weinstein (2011), Pravisini et al. (2011), Chor and Manova (2012), Bricongne et al. (2012), Behrens et al. (2013) and Ahn (2013).
} 
different payment forms (open account, CIA and L/C) in international trade and the cross country differences in their use. The model predicts that the firm in the country with the lower financing costs and the weaker contract enforcement should finance the trade transaction in order to minimize the interest costs and the commitment problem resulting from the failure of exporter or importer to meet their contractual obligations-including delivery and payment. Therefore, transaction should take place more frequently on OA terms when the contract enforcement in importing country is strong and the cost of financing trade in the exporting country is relatively cheap. In contrast, CIA method should be preferred if the financing costs in the exporting country are high and if the enforcement in the importing country is weak. When both firms locate in countries with weak contract enforcement, trade transaction need to be made on L/C terms. Using data on bilateral trade flows of 150 countries over the period 19802004, Schmidt-Eisenlohr (2013) indirectly tests the predictions of the payment contract choice model by aggregate gravity regressions and found evidence that, as predicted, financial conditions and contract environments both in exporting and importing country matter for trade. In particular, the empirical results show that countries with higher financial costs trade less with each other and the size of this effect increases as the geographical distance between trading partners, a proxy for time to trade, increase. Hoefele et al. (2013) takes a further step and directly test the predictions of the model utilizing the World Bank Enterprise Survey data for firms from 54 developing countries over the period between 2006 and 2009. Consistent with the model developed in Schmidt-Eisenlohr (2013), Hoefele et al. (2013) find that better enforcement and higher financing costs in the exporting country increases the use of pre-delivery payment (CIA).

The main problem of the aforementioned survey is that it does not break down the information on OA sales into domestic and international, even if it documents the share of exports in total sales. Antras and Foley (2013) are able to overcome this problem using detailed transaction-level data from a single large US exporter that exports frozen and refrigerated food products, mainly poultry. The data contain information on the financing terms used for each transaction between the US exporter and its customers located in more than 140 countries from 1996 to 2009. With the detailed actual data on financing terms, Antras and Foley (2013) investigate the effect of contract enforcement on the method of payment offered to importers, and find that exports to importers located in countries with weak contract enforcement and more distant from exporter's country is more likely to occur on CIA terms or $\mathrm{L} / \mathrm{C}$ terms. Their results further suggest that the use of post shipment method (OA) increases as the relationship between trading partners develops. In addition to the aforementioned studies, some studies have explicitly dealt with only one method of payment in great detail, namely L/C (see Glady and Potin, 2011; Ahn, 2011, 2013; Olsen, 2013; and Niepmann and Schmidt-Eisenlohr, 2013).

While the literature convincingly points out the importance of the essential linkages between trade finance and trade flows, the research on the choice of the payment method in trade flows and its evaluations during the financial crisis period, especially based on actual bilateral country-level trade finance data, remains limited. This paper, in next sections, aims to fill this gap in the literature by providing an in-depth descriptive analysis of trends on the usage of payment methods using a unique bilateral trade finance data from Turkey.

\section{Data}

TURKSTAT's database on methods of payments in Turkish trade, which contains the most detailed bilateral data in terms of trade finance instruments for over 270 countries (including the free-trade zones) classified according to the International Standard Industrial Classification of All Economic Activities (ISIC, Revision 3) at the 2-digit level, was used to evaluate the changing patterns of trade finance in Turkey over the period of 2002-2012. This unique database documents total amount of trade using a specific payment value in value (in thousands 
of US dollars at the current prices) and in quantities (where quantities are reported in different units of measure, such as kilograms, meters, liters, square meters, and such like) at the 2-digit level of ISIC Revision 3. Table A2 provides information about the structural characteristics of trade finance data as well as classification of each group from 2002 to 2012 on a yearly basis. Many different types of payment methods exist in the database and the types vary greatly from year to year. In order to make a consistent analysis from year-to-year, types of payment methods are grouped into five main categories: Open account (OA), cash-in advance (CIA), cash against documents $(\mathrm{CAD})$, letter of credit $(\mathrm{L} / \mathrm{C})$ and other, as shown in Table A2.

Beside free trade zones, we exclude some countries from our analysis, often due to the absence of trade or changes in political boundaries. Thus, bilateral trade finance data from Turkey with 206 countries over the period 2002-2012 at the 2-digit level of ISIC Revision 3 was used. In addition, we classified countries into 4 groups representing low income, lower middle income, upper middle income and high income groups. Classification of countries is from the World Bank, on the basis of 2009 gross national income (GNI) per capita. ${ }^{16}$ Countries are further divided into 6 regions based on the World Trade Organization's analytical regions (for a list of countries and information about regional and income group classifications, see Table A3). ${ }^{17}$ In carrying out the study, this paper focuses on manufacturing industries belonging to ISIC divisions 15-37, but excluding recycling (ISIC 37).

\section{Patterns of Payment Methods in Turkish Foreign Trade}

\section{1 Payment Methods in Turkish Exports}

Table 1 documents the average use of each payment method-OA, CIA, CAD and L/C- between 2002 and 2012. Despite being highly risky for exporters, 58\% of Turkish manufactured exports was executed by OA transactions (inter-firm trade finance). ${ }^{18}$ At the same time, the use of CIA method, represent a much smaller share $(6 \%)$. This finding is in line with the prediction of Schmidt-Eisenlohr's (2013) model that exports to importers located in countries with strong contract enforcement is more likely to occur on OA terms, given the fact that Turkey's exports are still heavily concentrated on European markets where contracts are more effectively enforced by courts, as compared to Turkey (Demir and Javorcik, 2014). As shown in Table 1, the average share of CAD-based exports is nearly $19 \%$ and $\mathrm{L} / \mathrm{C}$ is about $15 \%$, suggesting that the intermediated trade finance represents a relatively small fraction of all export arrangements in Turkey. This result is not surprising due to the fact that the intermediated trade finance are generally expensive method in terms of transaction and financial costs, making inter-firm trade finance more attractive option compared to the intermediated trade finance (Love, 2013).

\footnotetext{
${ }^{16}$ Detailed information can be found at the World Bank's website: http://data.worldbank.org.

17 Detailed information can be found at the World Trade Organization's website: http://www.wto.org.

18 The calculated shares are very similar to those reported in Malouche $(2009 \mathrm{~b})$, in which the average share of cash against goods, cash on delivery (OA) in manufactured exports is around $60 \%$ over the period between January 2008 and December 2009. The same pattern of findings also emerged in Demir (2014) and Demir and Javorcik (2014), in which the share of Turkish exports on OA terms (CAD is classified as OA) is around $80 \%$ over the period 2004-2011.
} 
Table 1: Average usage of methods of payments in trade by income and region, (in percent, 2002-2012)

\begin{tabular}{lcrrrrrrrrr}
\hline \multirow{2}{*}{ Sample } & \multicolumn{2}{c}{ OA } & \multicolumn{2}{c}{ CIA } & \multicolumn{2}{c}{ CAD } & \multicolumn{2}{c}{ L/C } & \multicolumn{2}{c}{ Other } \\
\cline { 2 - 12 } & Exp & Imp & Exp & Imp & Exp & Imp & Exp & Imp & Exp & \multicolumn{1}{c}{ Imp } \\
\hline LI & 45.91 & 9.72 & 8.92 & 40.37 & 15.69 & 22.57 & 28.49 & 22.99 & 0.99 & 4.34 \\
LMI & 48.00 & 20.75 & 8.85 & 38.70 & 17.32 & 14.86 & 24.11 & 22.90 & 1.72 & 2.78 \\
UMI & 52.99 & 18.16 & 8.68 & 56.33 & 20.14 & 10.22 & 16.34 & 13.13 & 1.85 & 2.16 \\
HI & 60.37 & 24.68 & 4.83 & 48.90 & 18.61 & 10.22 & 12.90 & 8.62 & 3.28 & 7.58 \\
Europe & 65.36 & 23.01 & 4.23 & 53.49 & 19.88 & 9.94 & 7.04 & 6.85 & 3.48 & 6.71 \\
America & 48.98 & 18.50 & 6.05 & 45.11 & 17.01 & 12.05 & 24.15 & 9.73 & 3.81 & 14.60 \\
Asia & 35.92 & 15.88 & 8.99 & 53.37 & 15.90 & 11.86 & 36.39 & 15.63 & 2.81 & 3.26 \\
Middle E. & 39.60 & 30.07 & 8.51 & 36.74 & 18.78 & 12.40 & 31.88 & 10.23 & 1.23 & 10.55 \\
CIS & 73.03 & 34.88 & 8.38 & 32.29 & 13.80 & 10.24 & 2.32 & 19.72 & 2.46 & 2.87 \\
Africa & 39.78 & 48.85 & 6.49 & 23.36 & 20.69 & 7.16 & 32.03 & 18.11 & 1.00 & 2.52 \\
Overall & 57.59 & 23.04 & 6.06 & 49.38 & 18.94 & 10.62 & 14.54 & 10.64 & 2.87 & 6.32 \\
\hline
\end{tabular}

Notes: Income classifications according to the World Bank classification: LI=Low Income; LMI=Lower Middle Income; UMI=Upper Middle Income; HI=High Income (See Table A1). Regional classifications according to the World Trade Organization classification (See Table A3).

Source: TURKSTAT, author's own calculations.

Figure 1a and 2a presents values and shares of each payment method in exports from 2002 to 2012. The share of exports financed through OA terms has risen $10 \%$ over the period, reducing the role of intermediated trade finance. This was largely due to the intense competition in traditional export markets fuelled by the recent financial crisis, as Turkish exporters have no choice but to offer more competitive OA terms. On the other hand, Figure 1a and 2a show that the use of CIA method dramatically increased in the last decade. In terms of its share in all methods of payments, CIA method increased almost fourfold, as indicated in Table 2. As is evident in Figure 1a, in 2012, more than 20 billion dollars of Turkish exports were executed via CIA compared to 500 million dollars in 2002. The change in the share of CIA sales appears more remarkable when compared to the $10 \%$ increase in the share of OA sales for the same time period, as Table 2 shows. The growing share of CIA method in Turkish exports is likely due to the re-orientation of Turkey's exports towards faster growing non-traditional markets (such as the Middle East and Africa) where the financial system is under-developed and contract enforcement is weak (Türkcan, 2014).

Figure 1: Trade by methods of payment (in million of US dollars, 2002-2012)

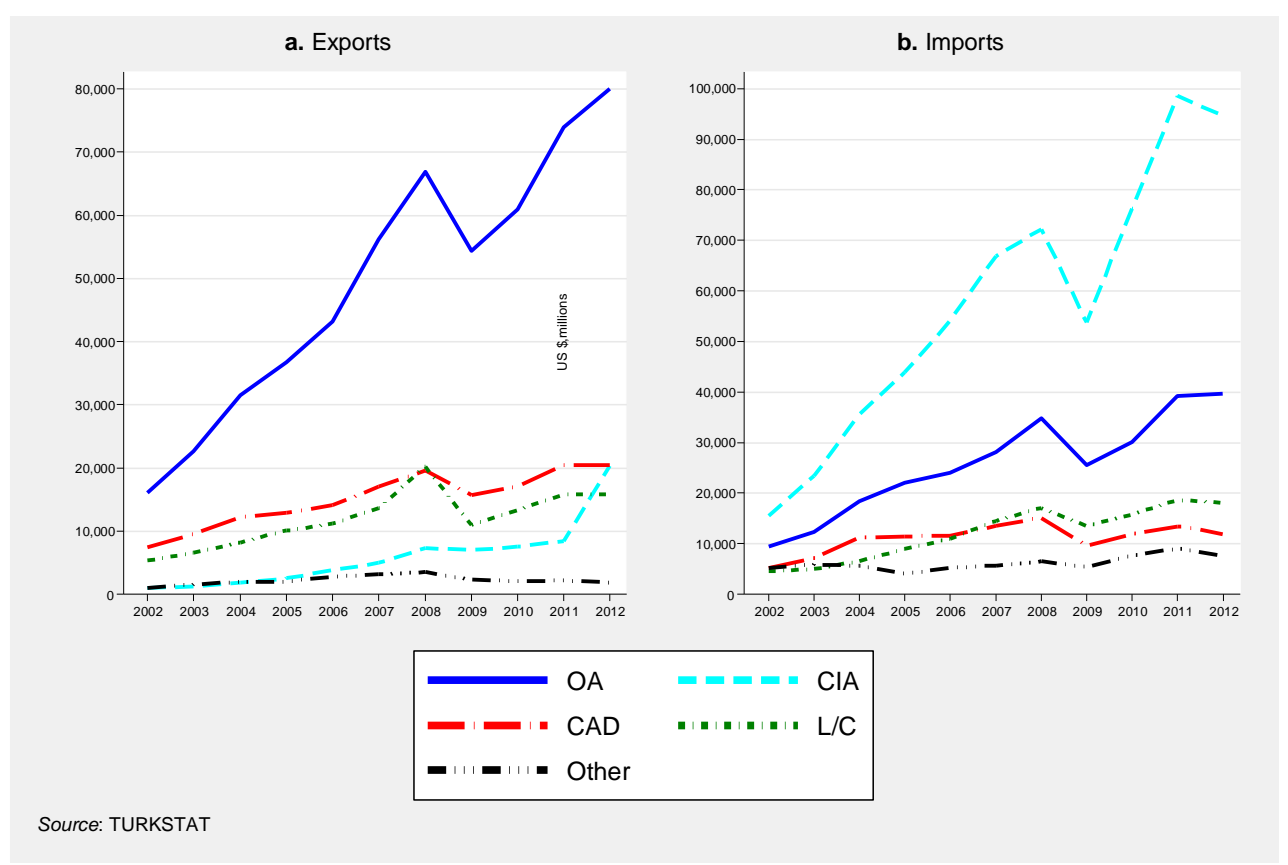


While the shares of inter-firm trade finance in Turkish exports increased significantly over the period, the shares of the intermediate trade finance dropped considerably. Figure 2a points out that the share of Turkish exports financed through CAD decreased from $24 \%$ in 2002 to $15 \%$ in 2012, whereas the share of L/C dropped from $17 \%$ to $14 \%$. These findings reflect with the fact that increased financial costs, and tightened credit conditions induced Turkish exporters rely increasingly on inter-firm trade finance over time (Malueche, 2009a). The shift away from the intermediated trade finance is also due to the recent global recession, which has led to the intensified competition in export markets, placing importers in a stronger negotiating position over payment terms. ${ }^{19}$

Table 2: Changes in shares of methods of payments in trade by income and region, (in percent, 2012 vs. 2002)

\begin{tabular}{lrrrrrrrrrr}
\hline \multirow{2}{*}{ Sample } & \multicolumn{2}{c}{ OA } & \multicolumn{2}{c}{ CIA } & \multicolumn{2}{c}{ CAD } & \multicolumn{2}{c}{ L/C } & \multicolumn{2}{c}{ Other } \\
\cline { 2 - 11 } & \multicolumn{1}{c}{ Exp } & \multicolumn{1}{c}{ Imp } & \multicolumn{1}{c}{ Exp } & \multicolumn{1}{c}{ Imp } & Exp & \multicolumn{1}{c}{ Imp } & \multicolumn{1}{c}{ Exp } & \multicolumn{1}{c}{ Imp } & Exp & Imp \\
\hline LI & -19.60 & -83.54 & 153.93 & 236.27 & 28.59 & -66.43 & -2.56 & 339.81 & 56.38 & 117.13 \\
LMI & 33.42 & -8.43 & 166.60 & 17.19 & -39.59 & -23.67 & -42.26 & 31.28 & -28.67 & -80.60 \\
UMI & -7.59 & -26.60 & 322.64 & 30.94 & -13.95 & -53.51 & -44.10 & -5.48 & -70.18 & -54.46 \\
HI & 21.90 & 6.39 & 299.62 & 43.53 & -45.72 & -47.97 & -39.65 & -28.14 & -56.01 & -61.27 \\
Europe & 26.81 & -5.41 & 128.92 & 58.11 & -47.85 & -52.84 & -42.30 & -38.80 & -44.34 & -74.82 \\
America & 29.15 & -19.88 & 51.90 & 17.05 & 40.80 & -17.60 & -57.56 & -29.21 & 178.71 & 18.88 \\
Asia & 113.80 & -18.83 & 13.98 & 33.02 & -27.75 & -31.72 & -44.82 & 18.05 & -9.48 & -88.07 \\
Middle E. & -13.57 & 75.99 & 641.76 & 22.96 & -10.76 & -39.87 & -58.64 & -76.96 & -65.25 & 9.62 \\
CIS & 15.74 & 9.80 & 263.52 & 4.44 & -44.71 & -73.11 & -44.31 & 35.76 & -94.12 & -8.75 \\
Africa & 31.27 & -10.05 & 77.62 & 35.33 & -35.63 & 28.69 & -11.85 & -28.41 & -49.63 & 67.41 \\
Overall & 10.94 & -3.30 & 374.02 & 41.66 & -38.91 & -45.99 & -34.08 & -6.99 & -60.09 & -66.09 \\
\hline
\end{tabular}

Notes: Income classifications according to the World Bank classification: LI=Low Income; LMI=Lower Middle Income; UMI=Upper Middle Income; HI=High Income (See Table A1). Regional classifications according to the World Trade Organization classification (See Table A3).

Source: TURKSTAT, author's own calculations.

We turn next to the comparison of payment methods for different income groups. As shown in Table 1, the share of OA method was observed as the highest in high income countries $(60 \%)$, while it was lowest when trading with low income countries $(46 \%){ }^{20}$ On the other hand, the evidence suggests that the share of CIA method was the highest for low income countries $(9 \%)$ whereas it was the lowest for high income countries (5\%), suggesting that Turkish exporters prefer safer methods of payment when trading with risky countries. Furthermore, the highest share of usage of L/C was seen for low income countries $(28 \%)$ while the lowest share was recorded for high income countries (13\%), mainly because of the perceived risk in the target country. As seen in Table 1, the shares of CAD method tend to be higher for upper income countries (20\%) and high income countries (19\%). It seems that when the risk to the exporter of non-payment is reduced, Turkish companies tend to rely more on less costly methods, namely CAD. These patterns suggest that Turkish companies tend to pay more attention to the quality of contract enforcement when dealing with low income countries whereas to the financial costs when trading with high income countries.

\footnotetext{
${ }^{19}$ BIS (2014) documents that the share of L/C in Turkish total exports has dropped from around $26 \%$ in 1998 to $15 \%$ in 2012 and suggest that the expanding network of long-term trade relationships reduces the need for L/C in Turkey over time.

${ }^{20}$ Love (2013) also found that OA terms are most often used when trading partners are located in high income countries.
} 
Figure 2: Share of trade by method of payments (in percent, 2002-2012)

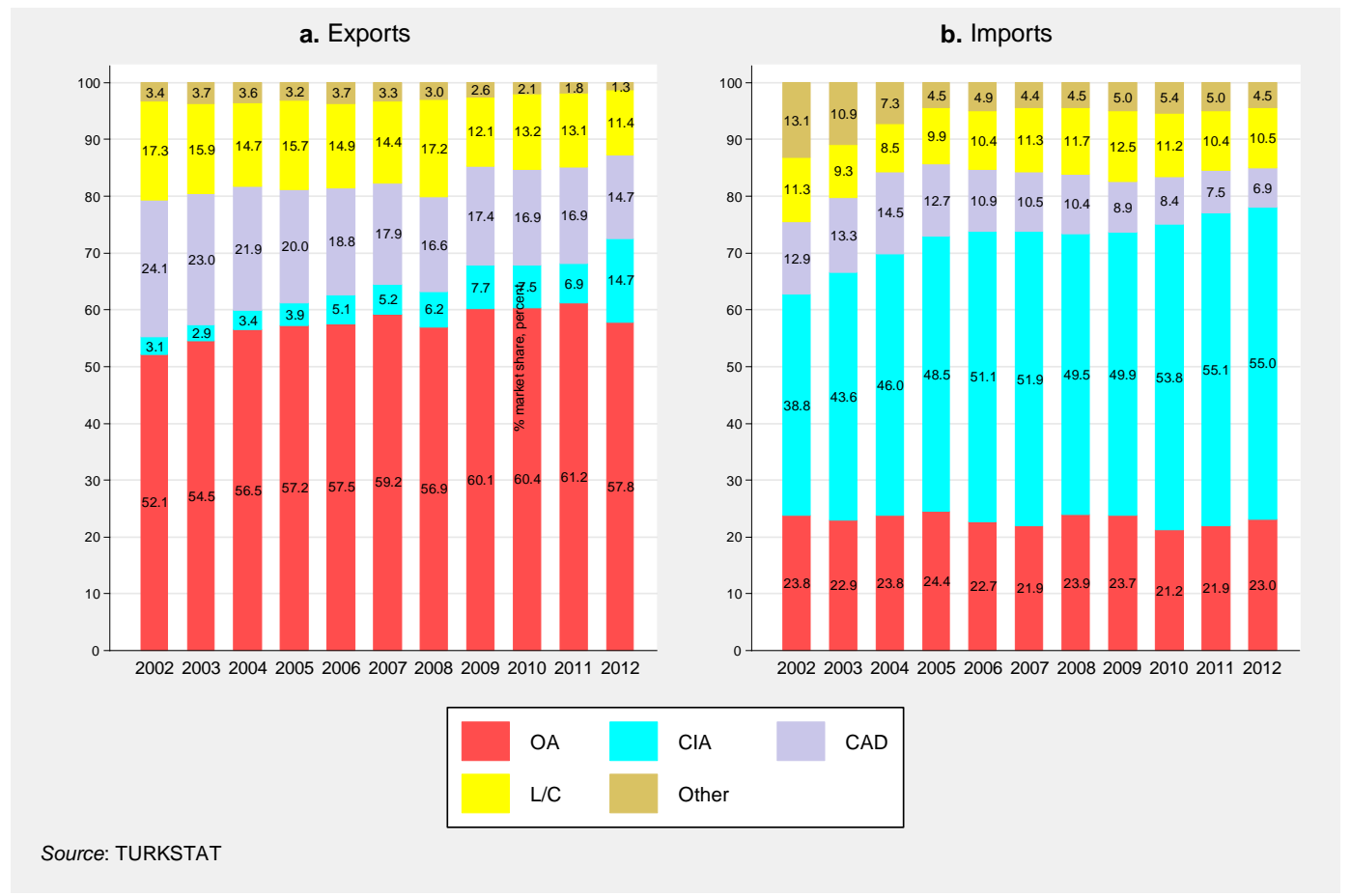

\section{Payment Methods in Turkish Exports by Income Levels}

Next to be analyzed is the evaluation of share of methods of payments in exports by income level. The statistics shown in Table 2 and Figure 3 reveals that the share of OA-based exports destined to lower middle income countries grew significantly at almost $33 \%$ over the periodfrom $43 \%$ in 2002 to $57 \%$ in 2012 . The corresponding share for high income countries also increased substantially from $53 \%$ to $64 \%$ over the sample period, with an increase of $22 \%$. By contrast, the share of OA-based exports declined considerably from $48 \%$ to $39 \%$ for low income countries, with an decline of $20 \%$, while its share have fell by $8 \%$, from $48 \%$ to $44 \%$ over the period. The increase in the use of OA-based exports is attributed to several factors, including the increased competition in the target markets (especially in high income countries) and the improved trade relations with countries (particularly with lower middle income and high income countries).

On the other hand, the statistics in Table 2 points out that the change in the use of CIA method stands out as the largest change in the pattern of trade finance in terms of income level comparisons of all payment methods. The results show that the share of CIA method has grown significantly for all income groups since 2002, but the increase is the most pronounced for upper middle income countries (323\%), followed by high income countries $(300 \%)$, lower middle income countries $(167 \%)$ and low income countries $(154 \%)$. This pattern again underlines the fact that the recent growth in the usage of CIA-based exports across all income groups is mainly due to the rising cost of financial intermediation, the lack of financing for importers (particularly in developing countries) and a substantial rise in the perceived risk of trade since the global financial crisis in 2008. The results further imply that the redirection of Turkish exports towards more dynamic emerging markets in which the quality of legal institutions is weak has resulted in an increase in the use of CIA method in total manufactured exports. 
Figure 3: Share of methods of payments in exports by income level (in percent, 2002-2012)

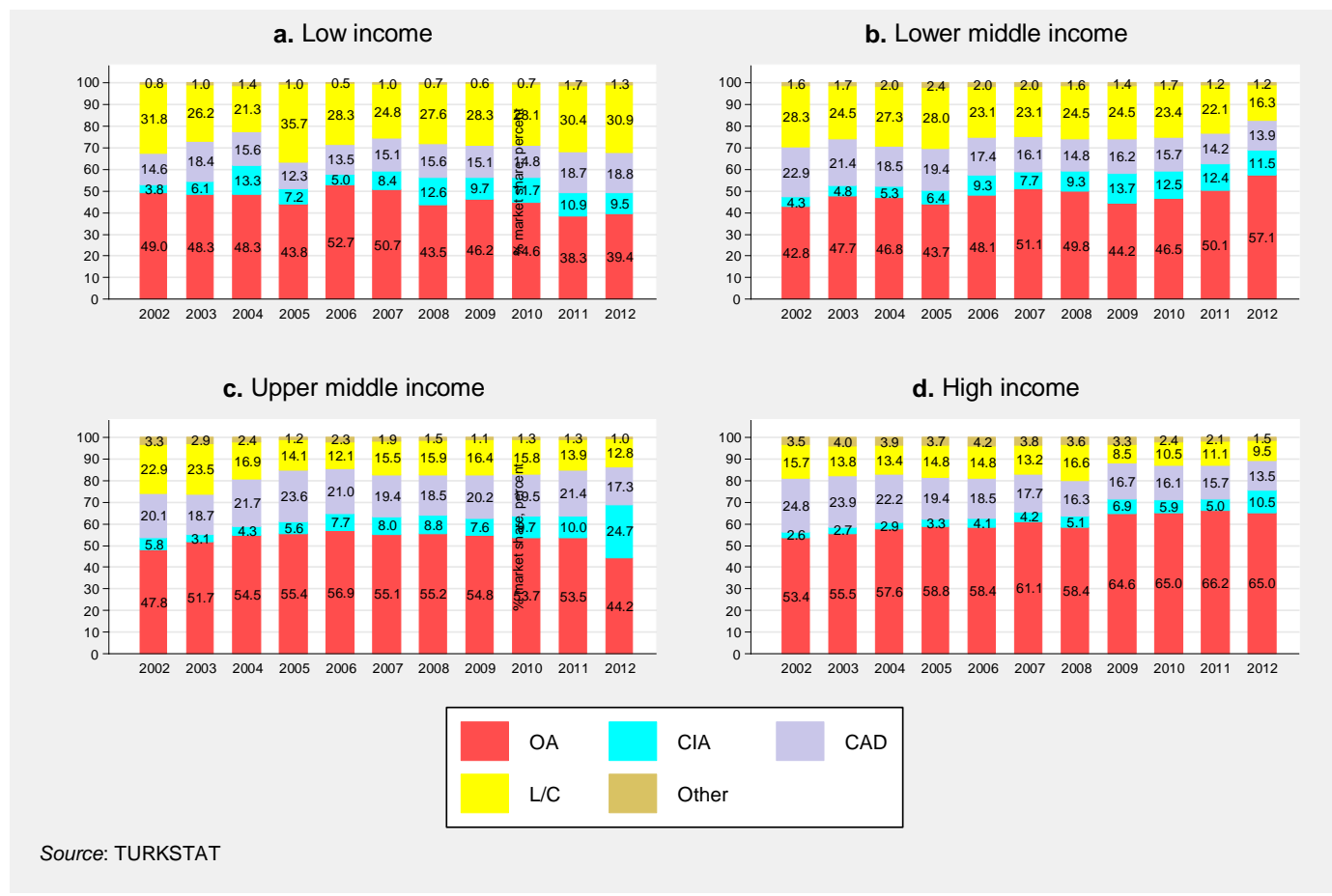

Moreover, as evident from Table 2 and Figure 3, the intermediated trade finance is losing ground to inter-firm trade finance in facilitating export transactions in Turkey across all income groups over time, with the exception of low income countries for the CAD transactions. In particular, Figure 3 shows that the largest decline in the shares of CAD payment methods were recorded for high income countries, 46\% decrease from 2002. Other income groups that experienced very large declines in the share of CAD transactions are lower middle income countries $(40 \%)$ and upper middle income groups (14\%). Similarly, all three income groups, with the exception of low income countries, experienced a significant decline in the shares of $\mathrm{L} / \mathrm{C}$ transactions in total manufactured exports over the sample period, but the decline is far more pronounced among upper middle income (44\%) and lower middle income countries $(42 \%)$, as shown in Table 2 . The results at the income level once again confirm that fear of default, tightening credit conditions and raising costs of financial intermediation is causing Turkish exporters to switch to less-expensive payment methods, which are generally less complicated and involve less documentation requirements than intermediated trade finance. The results further suggest that establishing or strengthening trade relationships with foreign firms (especially in lower income and upper income countries) also have reduced the use of the bank intermediated trade finance as a share of exports over time.

\section{Payment Methods in Turkish Exports by Destination Regions}

Table 1 documents that $\mathrm{OA}$ is the most common financing method across all regions with the exception of Asia which has on average $36 \%$ of total manufacturing exports were executed by the method of L/C. ${ }^{21}$ For the EU-zone countries as well as other developed countries, OA terms

\footnotetext{
${ }^{21}$ This finding is also observed in BIS (2014), which show that the Asia-Pacific region relies most heavily on L/C. The literature has identified several factors accountable for the higher usage of intermediated trade finance (L/C): longer distances between trading partners, newly formed trade relationships, weak enforcement of international contracts and under-developed banking sectors (Glady and Potin, 2011). In addition to these factors, in the context of Asia historical preferences, legal frameworks, regulatory differences as well as relatively cheap L/C fees are proposed (BIS, 2014).
} 
overwhelmingly dominate the transactions. Table 1 shows that on average $65 \%$ of total exports to Europe and $49 \%$ of total exports to America occurred under OA terms between 2002 and $2012 .{ }^{22}$ The OA terms are also most often used while trading with CIS countries $(73 \%)$. Although it is not clear why Turkish exporters relied to a larger extent on OA while dealing with CIS countries, one possible explanation is that these countries have weak banking systems and low levels of intermediation. CIA method was mostly preferred when trading with Asian (9\%), Middle Eastern (8.51\%) and CIS (8.38\%) countries, which is consistent with Love (2013) which suggests that the CIA terms are mostly used when trading with partners located in lowincome countries. Looking across different regions, the use of CAD transactions seemed to be relatively more important among African countries (21\%) and Middle Eastern countries (19\%), presumably reflecting greater need for reducing the risk of counterparty defaults. Likewise, $\mathrm{L} / \mathrm{C}$ account for relatively large shares of exports destined to Asia (36\%), Africa (32\%) and Middle East $(32 \%)$. In addition to the aforementioned factors, the distance appears to have significant effect on the choice of financing terms when traders take part in long-distance trade (Demir, 2014). This is also in line with the prediction of Antras and Foley (2013) which predicts that CIA terms and L/C terms are preferred to the post-shipment terms (OA) when there is more distance between partners.

Table 2 and Figure 4 show the increasing importance of inter-firm trade finance in Turkish exports from 2002 to 2012 . The shares of OA have increased considerably for all regions, except for Middle East, while the shares of CIA methods rose substantially across all regions, for the period 2002 to 2012. Perhaps, the most striking point in Table 2 is the large increase in CIA transactions for Middle Eastern countries since 2002. Turkish exporters preferred this method mostly because of the loss in confidence to the contract enforcement in these countries as this period coincides with political instability in the region. On the other hand, the increasing importance of OA transactions for Asian region is closely linked with the greater participation of Turkish exporters in the global value chains, which often involve repeated transactions and long term relationships between traders, consistent with the hypothesis of Cunat (2007) that repeated transactions will increase the amount of credit that suppliers are willing to provide. By contrast, the shares of $\mathrm{CAD}$ and $\mathrm{L} / \mathrm{C}$ have declined noticeably across all regions over the same period, suggesting that Turkish exporters generally prefer inter-firm trade finance instruments rather than relatively expensive bank intermediated trade finance instruments to remain competitive internationally.

22 The similar patterns were also noted in Love (2013). 
Figure 4: Share of methods of payments in exports by region (in percent, 2002-2012)

a. Europe

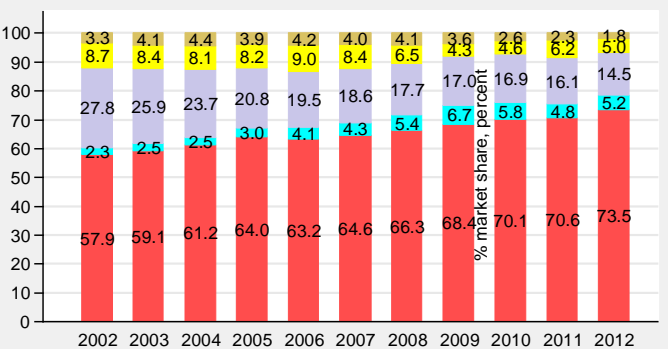

c. America

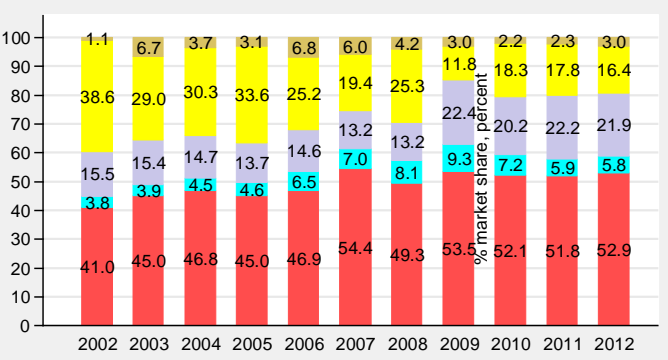

e. Asia

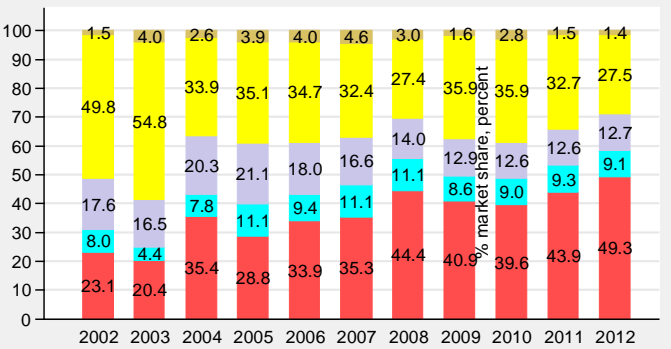

b. Middle East

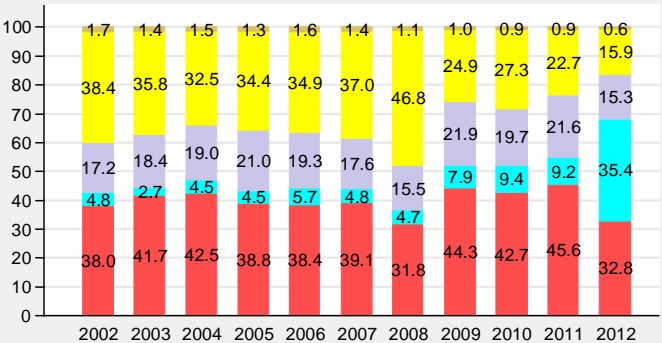

d. CIS

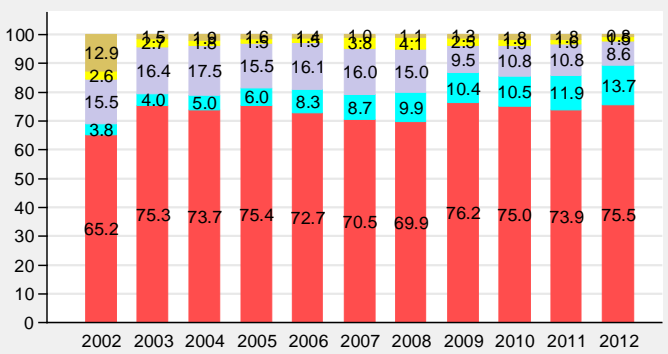

f. Africa

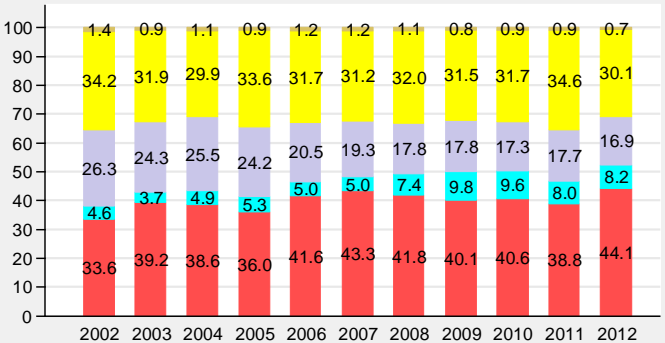

CAD

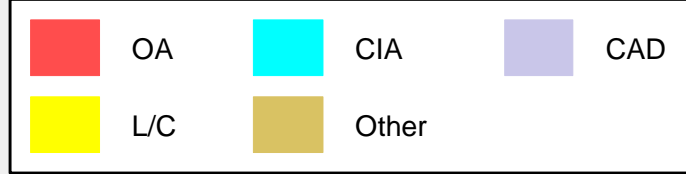

Source: TURKSTAT

\section{2 Payment Methods in Turkish Imports}

We next examine average share of methods of payments in Turkish imports between 2002 and 2012 in Table 1. As opposed to exports, the majority of import transactions take place under CIA terms (49\%), which can be considered the most risky term for the importers. It is followed by OA $(23 \%), \mathrm{L} / \mathrm{C}(11 \%)$ and CAD $(11 \%)$. The results suggest that Turkish importers have low bargaining power against foreign suppliers. This is because of their higher default risk due to the difficulties of enforcing contracts in Turkey compared to firms located in advanced countries with well established legal systems. As a consequence, CIA payment method is the most preferred financing method in Turkish imports. This finding is in line with the findings of Antras and Foley (2013) that exporters demand CIA payment from their high default risk importers. In addition, it is also evident from Table 1 that the share of inter-firm trade finance (OA plus CIA) in imports (72\%) is much larger than in exports $(63 \%)$, indicating that Turkish 
importers relied more on inter-firm trade finance compared to exports. The relatively smaller share of the intermediated finance in imports can be explained mainly by the lack of access to finance in Turkey which is particularly critical to small and medium enterprises' (SMEs) growth and export activities. This forces Turkish importers to use the riskiest methods of payment in financing imports, namely CIA method.

Despite being highly risky for importer, the share of CIA methods has increased even more over the years, making Turkish importers even more vulnerable to payment risks: the share of CIA payment reached $55 \%$ in 2012, up from $39 \%$ in 2002, as seen in Figure $2 \mathrm{~b}$. Meanwhile, the share of OA in imports has declined slightly from $23.8 \%$ in 2002 to $23 \%$ in 2012 . This is in contrast with the previous literature which finds increasing share of OA in international trade (See ICC, 2009). The shift from OA transactions to CIA terms shows that the level of perceived risk of defaults rose suddenly in global markets after the 2008-2009 financial crisis but recedes only gradually after the crisis, which still forces importers to look for more security in the transaction. Table 2 also documents a declining trend for both $\mathrm{CAD}$ and $\mathrm{L} / \mathrm{C}$ over the time where the decline is more pronounced in the case of CAD. As seen in Table 2, the share of CAD declined by nearly $45 \%$, while the share of L/C fell by just below $7 \%$ during the 2002 2012 period, reducing the role of bank intermediated finance in imports. This finding suggests that inter-firm trade finance, especially CIA term, is relatively more prevalent in countries with weaker contractual enforcement, less financial development and higher political risk (See BIS, 2014; Love, 2013).

\section{Payment Methods in Turkish Imports by Income Levels}

Looking at the average shares of methods of payments at the income level reported in Table 1, we observe that OA method is less preferred when Turkish firms import from countries which has an income level lower than Turkey. OA terms represents only 10\% of Turkish imports originated from low income countries whereas it represented a $25 \%$ share of Turkish imports from high income countries. In terms of CIA payment transactions, there is again a systematic difference across income groups: the share of CIA terms is consistently higher for upper income (56\%) and high income countries (49\%) compared to low income (40\%) and lower middle income countries $(39 \%)$. The evidence thus suggest that Turkish importers have a better bargaining power when negotiating payment terms with firms located in developing countries. In contrast, Turkish importers have weak negotiating power over payment terms when dealing with firms located in advanced countries, forcing them to accept the risky method of payment, i.e. CIA payment terms. The results are in line with the theoretical predictions developed in Schmidt-Eisenlohr (2013) and Antras and Foley (2013).

When looking at the average shares of intermediated trade finance in Turkey's imports in Table 1, we observe that the shares of CAD and $\mathrm{L} / \mathrm{C}$ are consistently higher for low and lower middle income countries. The shares of CAD and L/C terms, however, are considerably lower when Turkish importers trade with advanced countries. The shares of CAD and $\mathrm{L} / \mathrm{C}$ is smallest in high income group (10\% and 9\%, respectively) and largest in low income group (23\% and $23 \%$, respectively). This pattern underlines the fact Turkish importers rely mostly on banks to facilitate imports from less-developed countries because both CAD and L/C terms protects them by ensuring that goods have been shipped as agreed.

When comparing 2012 to 2002 in Table 2 and Figure 5, the shares of OA transactions declined in all but one income group. The largest decline in shares of OA transactions were registered for the low income group, down from $40 \%$ in 2002 to $7 \%$ in 2012 . The exception in this category is the high income group, where it shows a slight increase from $24 \%$ to $26 \%$. On 
the other hand, Table 2 and Figure 5 point out an increasing share of CIA transactions in imports across all regions over the period. The increase in the share of CIA transactions was the largest in low income countries (from 14\% in 2002 to $47 \%$ in 2012). In the meantime, the share of CAD has declined uniformly across all income groups. However, when looking at the shares of $\mathrm{L} / \mathrm{C}$, we observe that the share of $\mathrm{L} / \mathrm{C}$ has increased substantially for low income and lower income groups while it declined marginally for upper middle and high income groups over the same period. These patterns show that Turkish firms prefer CIA transactions or $\mathrm{L} / \mathrm{C}$ in importing when dealing with trading partners located in less-developed countries. This outcome is quite plausible because a significant portion of the increase in Turkish imports in recent years originated from developing countries where the suppliers do not have an established relationship with Turkish buyers (See Table 3). As stated above, both CIA and L/C terms are typically used in newly formed trade relationships.

Figure 5: Share of methods of payments in imports by income level (in percent, 2002-2012)

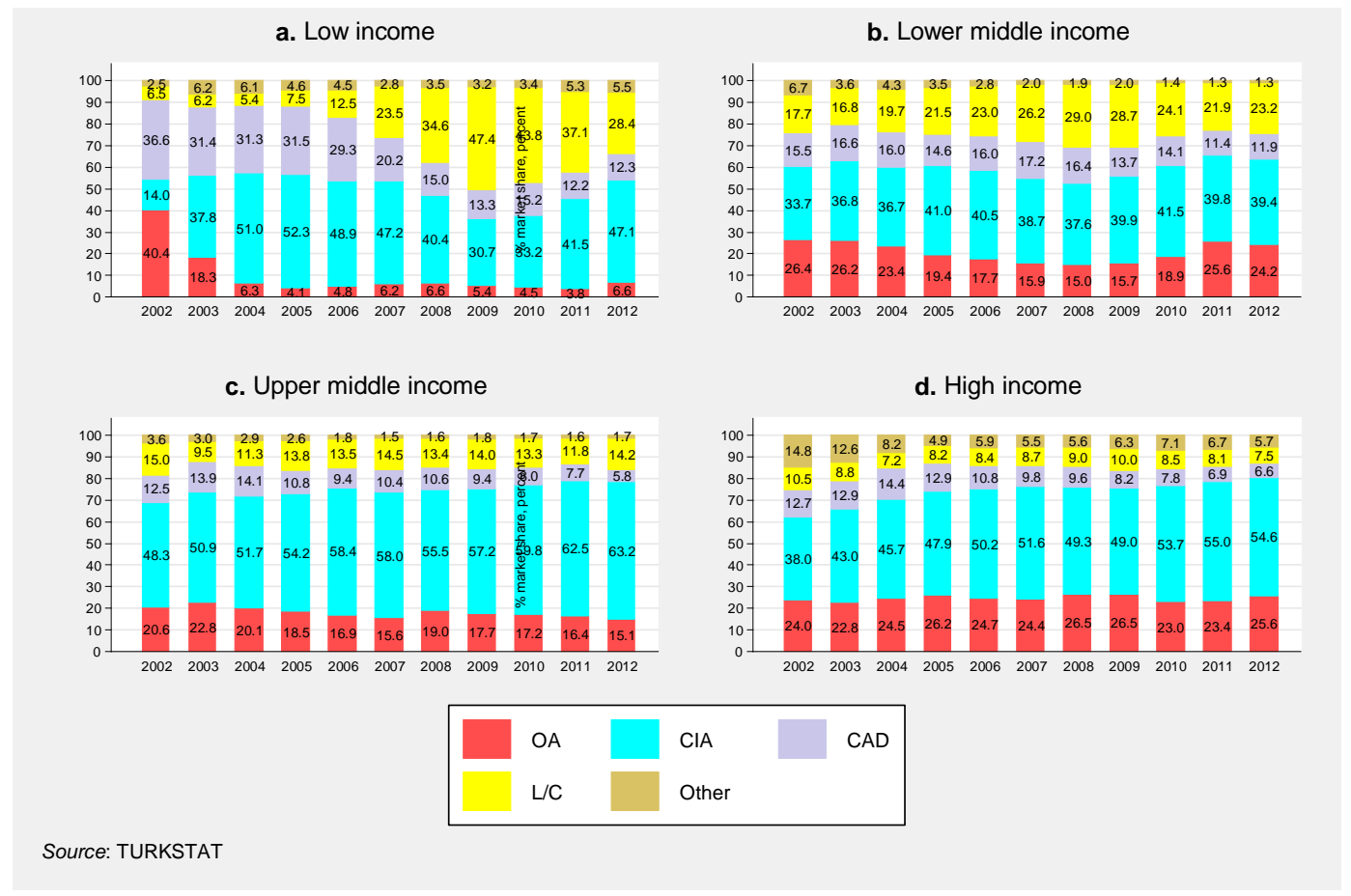

Table 3: Changes in value and shares of Turkey's trade by income and region, (2012 vs. 2002)

\begin{tabular}{|c|c|c|c|c|c|c|c|c|c|c|c|c|}
\hline \multirow{3}{*}{ Sample } & \multicolumn{6}{|c|}{ Value (\$ millions) } & \multicolumn{6}{|c|}{ Share (\%) } \\
\hline & \multicolumn{3}{|c|}{$\operatorname{Exp}$} & \multicolumn{3}{|c|}{ Imp } & \multicolumn{3}{|c|}{ Exp } & \multicolumn{3}{|c|}{ Imp } \\
\hline & 2002 & 2012 & $\begin{array}{c}\text { Change } \\
(\%)\end{array}$ & 2002 & 2012 & $\begin{array}{c}\text { Change } \\
(\%)\end{array}$ & 2002 & 2012 & $\begin{array}{c}\text { Change } \\
(\%)\end{array}$ & 2002 & 2012 & $\begin{array}{c}\text { Change } \\
(\%)\end{array}$ \\
\hline LI & 178 & 2,551 & $1,334.40$ & 86 & 1,472 & $1,603.06$ & 0.57 & 1.84 & 220.47 & 0.22 & 0.86 & 293.93 \\
\hline LMI & 1,645 & 11,569 & 603.39 & 2,122 & 15,432 & 627.19 & 5.32 & 8.36 & 57.15 & 5.33 & 8.97 & 68.20 \\
\hline UMI & 3,690 & 40,480 & 996.96 & 4,234 & 36,834 & 769.89 & 11.93 & 29.24 & 145.08 & 10.64 & 21.41 & 101.21 \\
\hline $\mathrm{HI}$ & 25,415 & 83,830 & 229.85 & 33,350 & 118,297 & 254.71 & 82.18 & 60.56 & -26.31 & 83.81 & 68.76 & -17.95 \\
\hline Europe & 19,697 & 59,371 & 201.42 & 27,036 & 85,926 & 217.82 & 63.69 & 42.89 & -32.66 & 67.94 & 49.95 & -26.49 \\
\hline America & 3,706 & 9,184 & 147.82 & 2,988 & 12,224 & 309.08 & 11.98 & 6.63 & -44.63 & 7.51 & 7.11 & -5.38 \\
\hline Asia & 1,089 & 5,193 & 377.04 & 5,512 & 43,630 & 691.50 & 3.52 & 3.75 & 6.58 & 13.85 & 25.36 & 83.08 \\
\hline Middle E & 2,905 & 37,295 & $1,183.60$ & 938 & 9,852 & 950.63 & 9.39 & 26.94 & 186.78 & 2.36 & 5.73 & 143.02 \\
\hline CIS & 2,050 & 14,919 & 627.72 & 2,516 & 16,690 & 563.45 & 6.63 & 10.78 & 62.58 & 6.32 & 9.70 & 53.46 \\
\hline Africa & 1,480 & 12,467 & 742.39 & 803 & 3,713 & 362.29 & 4.79 & 9.01 & 88.20 & 2.02 & 2.16 & 6.93 \\
\hline Overall & 30,927 & 138,429 & 347.59 & 39,793 & 172,035 & 332.32 & & & & & & \\
\hline
\end{tabular}

Notes: Income classifications according to the World Bank classification: LI=Low Income; LMI=Lower Middle Income; UMI=Upper Middle Income; HI=High Income (See Table A1). Regional classifications according to the World Trade Organization classification (See Table A3).

Source: TURKSTAT, author's own calculations. 


\section{Payment Methods in Turkish Imports by Destination Regions}

Table 1 displays the average usage of payment methods in Turkish imports by destination region. As expected, the large fraction of imports originated from non-traditional markets is financed through the method of OA while imports from traditional markets are mainly financed through CIA method. In particular, the highest share of OA in imports is observed for Africa (49\%). Other source destinations with relatively higher shares of OA are the CIS (35\%) and the Middle East (30\%). By contrast, the CIA terms has been extensively used when Turkish importers deal with trading partners from Europe (53\%), Asia (53\%) and America (45\%). This finding also supports the previous finding that Turkish companies have low bargaining power in dealing with the sellers from advanced countries.

The results in Table 1 further show that the Middle East (12.40\%) has the highest share of CAD in imports, but there are other regions with rather high shares of CAD, such as America $(12.05 \%)$ and Asia (11.86\%). In addition, it was found that the CIS (19\%) has the highest share of L/C in imports, followed by Africa (18\%) and Asia (16\%). From figures in Table 1, we conclude that Turkish companies are more concerned with the risk of non-delivery than with the cost of the intermediated trade finance when they import products from the sellers located in developing countries and also located at a long distance.

Table 2 and Figure 6 present the evolution of trade finance patterns in imports by region. As evident from Table 2, there is a significant change in the composition of payment methods of imports across all regions. In the concerned period, the share of OA terms in Turkish imports has declined significantly across all regions, with the exception of Middle East and CIS. In contrast, there is a significant increase in CIA transactions in imports across all regions over the sample period. At the same time, there is a significant decline in the popularity of CAD across all regions. In addition, sharp declines in the share of $\mathrm{L} / \mathrm{C}$ were registered across all regions, except Asia and CIS. This pattern again underlines the fact that there is significant move towards the CIA methods in imports over the period. The regional results suggest that importers in Turkey still suffer from the financial constraints (the high cost and lack of finance to support import) caused by the financial crisis of 2008-2009. The results further indicate that foreign exporters have become more risk averse when dealing with Turkish importers in recent years, especially since the 2008-2009 global financial crisis. 
Figure 6: Share of methods of payments in imports by region (in percent, 2002-2012)

\section{a. Europe}

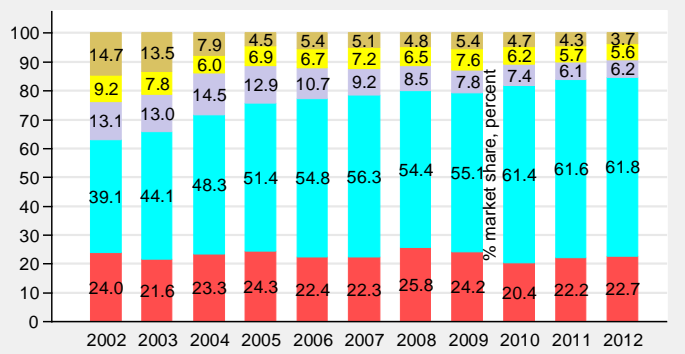

c. America

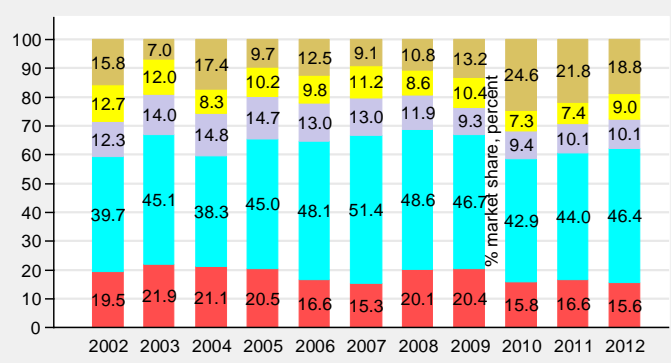

e. Asia

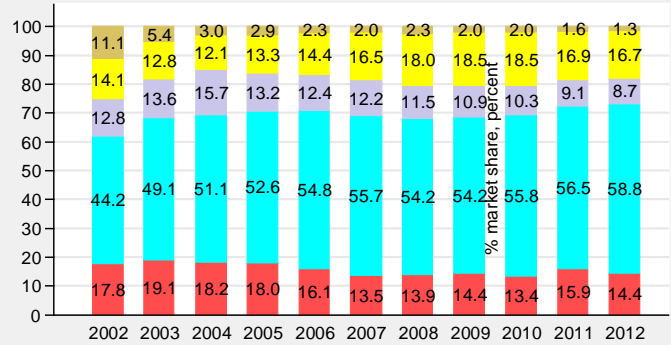

b. Middle East

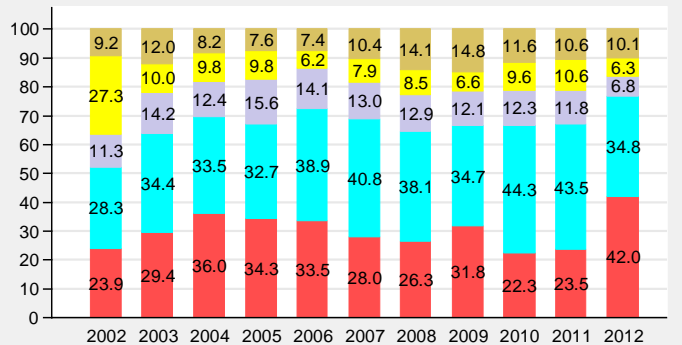

d. CIS

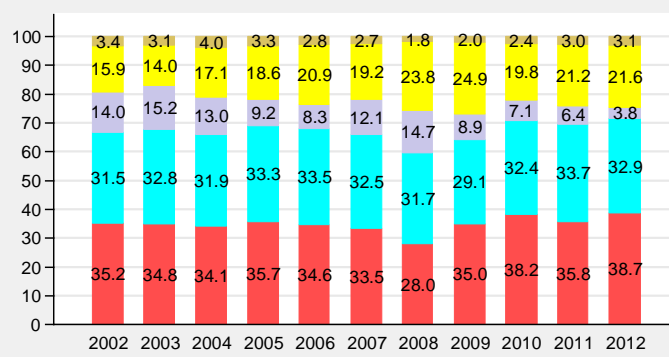

f. Africa

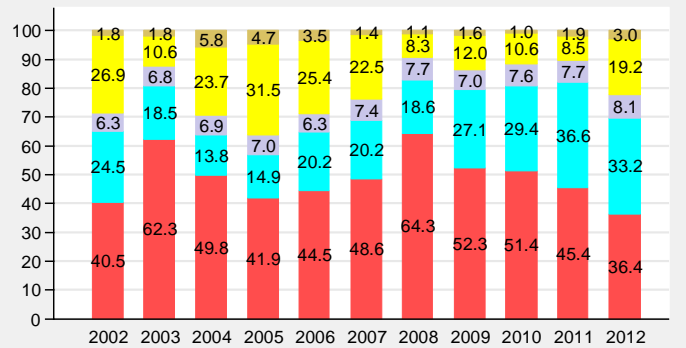

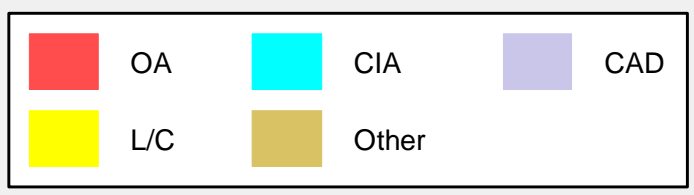

Source: TURKSTAT

\section{Changing Patterns of Payment Methods in Turkish Foreign Trade during the 2008-2009 Global Financial Crisis}

The 2008-2009 global financial crisis -the worst since the Great Depression- had led to a sharp reduction in Turkish trade. As shown in Table 4, Turkey's exports of manufactured goods fell by $23 \%$ in 2009 to 90.3 billion US\$ from 117.5 billion US\$ in 2008 . The fall in the value of imports was even sharper. Turkey's imports decreased by $26 \%$ to 107.8 billion US\$ in 2009 from 145.8 billion US\$ in 2008. Not surprisingly, overall Turkish exports experience a sharp decline in 2008-2009 period, but recovers in 3 years following the crisis. The international financial crisis had also dramatic effects on the trade financing in Turkey. 
Table 4: Changes in value and shares of Turkey's trade by income and region, (2009 vs. 2008)

\begin{tabular}{|c|c|c|c|c|c|c|c|c|c|c|c|c|}
\hline \multirow{3}{*}{ Sample } & \multicolumn{6}{|c|}{ Value (\$ millions) } & \multicolumn{6}{|c|}{ Share (\%) } \\
\hline & \multicolumn{3}{|c|}{ Exp } & \multicolumn{3}{|c|}{ Imp } & \multicolumn{3}{|c|}{ Exp } & \multicolumn{3}{|c|}{ Imp } \\
\hline & 2008 & 2009 & $\begin{array}{c}\text { Change } \\
(\%)\end{array}$ & 2008 & 2009 & $\begin{array}{c}\text { Change } \\
(\%)\end{array}$ & 2008 & 2009 & $\begin{array}{c}\text { Change } \\
(\%)\end{array}$ & 2008 & 2009 & $\begin{array}{c}\text { Change } \\
(\%)\end{array}$ \\
\hline LI & 1,432 & 1,421 & -0.77 & 678 & 722 & 6.58 & 1.22 & 1.57 & 29.12 & 0.46 & 0.67 & 44.15 \\
\hline LMI & 9,023 & 8,353 & -7.43 & 12,335 & 8,111 & -34.24 & 7.68 & 9.25 & 20.46 & 8.46 & 7.52 & -11.06 \\
\hline UMI & 23,145 & 21,100 & -8.84 & 30,102 & 22,203 & -26.24 & 19.69 & 23.36 & 18.63 & 20.64 & 20.59 & -0.24 \\
\hline HI & 83,941 & 59,456 & -29.17 & 102,763 & 76,818 & -25.25 & 71.41 & 65.82 & -7.83 & 70.44 & 71.22 & 1.11 \\
\hline Europe & 64,798 & 49,495 & -23.62 & 75,508 & 55,815 & -26.08 & 55.13 & 54.79 & -0.61 & 51.76 & 51.75 & -0.02 \\
\hline America & 6,255 & 4,567 & -26.98 & 10,281 & 8,077 & -21.44 & 5.32 & 5.06 & -4.98 & 7.05 & 7.49 & 6.25 \\
\hline Asia & 4,062 & 3,594 & -11.53 & 32,189 & 25,188 & -21.75 & 3.46 & 3.98 & 15.13 & 22.07 & 23.35 & 5.84 \\
\hline Middle E & 22,193 & 16,081 & -27.54 & 4,331 & 3,438 & -20.62 & 18.88 & 17.80 & -5.71 & 2.97 & 3.19 & 7.36 \\
\hline CIS & 12,754 & 7,720 & -39.47 & 20,393 & 13,116 & -35.68 & 10.85 & 8.55 & -21.24 & 13.98 & 12.16 & -13.01 \\
\hline Africa & 7,480 & 8,874 & 18.63 & 3,176 & 2,220 & -30.10 & 6.36 & 9.82 & 54.36 & 2.18 & 2.06 & -5.46 \\
\hline Overall & 117,542 & 90,330 & -23.15 & 145,878 & 107,854 & -26.07 & & & & & & \\
\hline
\end{tabular}

Notes: Income classifications according to the World Bank classification: LI=Low Income; LMI=Lower Middle Income; UMI=Upper Middle Income; HI=High Income (See Table A1). Regional classifications according to the World Trade Organization classification (See Table A3).

Source: TURKSTAT, author's own calculations.

Table 5 documents the changes in shares of methods of payments due to 2008-2009 crises. While Turkey's manufacturing exports fell drastically by $23.15 \%$ during the crisis, the share of the CIA was surprisingly increased by around $24 \% .{ }^{23}$ This means that Turkish exporters started to accept more CIA transactions, the safest method of payment, during the crisis. Perhaps, the most striking point in Table 5 is the large increase in CIA transactions for Middle Eastern countries after the crises. Turkish exporters preferred this method mostly because of the loss in confidence to the contract enforcement in these countries as this period coincides with political instability in the region. This shift towards the CIA method when trading with the Middle Eastern countries also had a large negative impact on the volume of trade. ${ }^{24}$ Table 4 shows that Turkey's total exports to the Middle Eastern countries was decreased by $27.5 \%$ after the global recession. This point can also partially explain the deflection of trade to the African countries after the crisis. ${ }^{25}$ A similar trend emerges for the share of the OA in Turkish exports over the same period, but in a much lower scale. The amount of increase in the shares of OA transactions has been around $6 \%$ from 2008 to 2009 . These figures reflect the fact that Turkish firms still offer competitive OA terms in order to gain customers and not lose any, following the onset of the financial crisis (Acar, 2009).

\footnotetext{
${ }^{23}$ This finding is broadly consistent with the findings reported in Eck (2012) who documents a rising importance of CIA payment method relative to the pure bank financing for a sample of European and Central Asian firms during the crisis.

${ }^{24}$ It is important to bear in mind that several empirical studies including Bricongne et al. (2012) and Behrens et al. (2013) suggest that contraction in trade finance was not main driver behind the 2008-2009 trade collapse; rather, the collapse of aggregate demand and the decline in commodity prices were the leading causes of the sharp decline in trade.

${ }^{25}$ Table 4 shows a large increase in the share of exports to the African countries.
} 
Table 5: Changes in shares of methods of payments in trade due to 2008-2009 crisis by income and region, (in percent, 2009 vs. 2008)

\begin{tabular}{|c|c|c|c|c|c|c|c|c|c|c|}
\hline \multirow{2}{*}{ Sample } & \multicolumn{2}{|c|}{$\mathbf{O A}$} & \multicolumn{2}{|c|}{ CIA } & \multicolumn{2}{|c|}{ CAD } & \multicolumn{2}{|c|}{$\mathrm{L} / \mathrm{C}$} & \multicolumn{2}{|c|}{ Other } \\
\hline & Exp & Imp & Exp & Imp & Exp & Imp & Exp & Imp & Exp & Imp \\
\hline LI & 6.29 & -17.67 & -22.58 & -24.05 & -3.01 & -10.89 & 2.39 & 37.08 & -12.27 & -8.90 \\
\hline LMI & -11.29 & 4.67 & 47.88 & 6.02 & 9.12 & -16.67 & 0.17 & -0.93 & -12.11 & 2.05 \\
\hline UMI & -0.75 & -6.92 & -14.27 & 3.09 & 8.63 & -11.12 & 3.04 & 4.28 & -27.05 & 12.77 \\
\hline $\mathrm{HI}$ & 10.62 & -0.13 & 35.20 & -0.51 & 2.34 & -14.36 & -48.85 & 11.58 & -7.14 & 11.01 \\
\hline Europe & 3.21 & -6.27 & 22.57 & 1.32 & -4.05 & -8.58 & -33.58 & 16.47 & -10.91 & 11.66 \\
\hline America & 8.52 & 1.31 & 15.06 & -4.03 & 70.30 & -21.94 & -53.37 & 21.52 & -28.05 & 22.91 \\
\hline Asia & -7.86 & 3.60 & -22.67 & -0.08 & -7.67 & -4.86 & 30.92 & 2.69 & -46.11 & -16.38 \\
\hline Middle E. & 39.01 & 20.72 & 67.94 & -8.92 & 41.72 & -6.60 & -46.91 & -22.77 & -10.32 & 5.31 \\
\hline CIS & 9.12 & 25.19 & 4.88 & -7.96 & -36.49 & -39.16 & -38.11 & 4.29 & 18.01 & 10.39 \\
\hline Africa & -4.00 & -18.70 & 33.37 & 45.64 & 0.20 & -9.02 & -1.71 & 45.52 & -25.11 & 44.89 \\
\hline Overall & 5.63 & -0.75 & 23.72 & 0.74 & 4.80 & -14.36 & -29.53 & 6.74 & -13.38 & 11.54 \\
\hline
\end{tabular}

Notes: Income classifications according to the World Bank classification: LI=Low Income; LMI=Lower Middle Income; UMI=Upper Middle Income; HI=High Income (See Table A1). Regional classifications according to the World Trade Organization classification (See Table A3).

Source: TURKSTAT, author's own calculations.

Another interesting fact observed from the industry data is that the use of $\mathrm{L} / \mathrm{C}$ in Turkish exports decreased in the post-crises era. ${ }^{26}$ This finding is not surprising given the fact that the $\mathrm{L} / \mathrm{C}$ fees increased substantially because of the worldwide financial meltdown (Asmundson et al., 2011). In fact, the share of the use of $\mathrm{L} / \mathrm{C}$ in Turkish exports was decreased by around $30 \%$ shortly after the global recession in 2008 (Table 5). A sharper decrease (48\%) is observed in $\mathrm{L} / \mathrm{C}$ transactions for the exports to the developed countries. The largest decline in the growth rate of exports after the global recession was also observed for the exports to the developed countries (Table 4). This finding is consistent with the anecdotal evidence that banks in developed countries, particularly in Europe, retreated from the trade-finance market during the crisis period (BIS, 2014). This implies that the drastic decline in Turkish exports in times of crisis was the result not only for lower imports from Europe, but also of the contraction in trade financing in some developed countries, in particular in Europe (Kalkan et al., 2010). However, at the same time, the usage of CAD has been increased slightly by around 5\% during the crisis period, indicating that trading partners are forced to use a less expensive method of payments, namely $\mathrm{CAD}$ comparing to $\mathrm{L} / \mathrm{C}$ transactions in times of crisis.

However, during the crisis period no such significant change has been observed regarding the usage of OA method in import transactions, as Table 5 illustrates. The share of OA in Turkish imports has declined by nearly 1\% between 2008 and 2009. Conversely, the share of CIA rose by around $1 \%$ during the crisis. Interestingly, evidence from Table 5 suggests that the usage of intermediated trade finance in imports have been more affected by the financial crisis. The share of the CAD has dropped dramatically by around $14 \%$ whereas the share of $\mathrm{L} / \mathrm{C}$ has increased by around $7 \%$ during the crisis era. The findings confirmed that exporters, particularly in Europe and America, shifted away from risky OA transactions towards lower-risk bankintermediated financing, namely $\mathrm{L} / \mathrm{C}$, because of heightened uncertainty and increased counterparty risk during the crisis period. ${ }^{27}$ As it pointed before, $\mathrm{L} / \mathrm{C}$ is considered the most secure method of payment for the exporter but the most expensive for the importer when compared with the cash against goods terms. The results thus suggest that the global financial crisis has put further financial pressure on Turkish firms to fund their import transactions. In sum, an assessment of the impact of 2008-2009 global financial crisis on Turkey's foreign trade

\footnotetext{
${ }^{26}$ Malouche (2009a) also found that the value of L/C issued by the Turkish banking sector declined by $25 \%$ between September and December 2008.

27 This finding is line with Chauffour and Farole (2009) who claim that trading partners have resorted to more formal, bank intermediated instruments to finance trade since the outbreak of the financial crisis in order to reduce the high probability of default in OA financing.
} 
revealed that many of the Turkish exporters began relying more heavily on inter-firm credit finance whereas importers have increased the use of bank intermediate finance.

\section{Conclusion}

Trade finance is a vital element of global trade and more than $90 \%$ of international transactions are underpinned by some form of trade finance, mainly short-term (Auboin, 2007). Following the financial crisis in 2008-2009, survey reports show that this credit has become more expensive and the global trade experienced a substantial decline in consequence. ${ }^{28}$ Consequently, many researchers made strenuous efforts to understand the structure and functioning of the trade finance market, and their role and impact on trade flows in times of financial crisis. Attempts to understand the structure and recent evolution of the trade finance market, and the relationship between changes in trade finance and international trade during the financial crisis period may provide useful information to policy makers in formulating effective and timely measures in times of crisis (ICC, 2010). In this regard, the present paper attempted to investigate the structure and evaluation of trade financing across income groups, regions as well as industry groups using a unique bilateral trade finance data from Turkey with 206 countries over the period 2002-2012 at the 2-digit level of ISIC Revision 3. Further, for the purposes of this paper, the present paper attempted to document the changes in shares of methods of payments due to the 2008-2009 crisis.

Using actual data on the method of payments in Turkey's foreign trade, we first observed that OA terms (inter-firm trade finance) dominate the cross border transactions in terms of exports. Second, OA terms were mostly used when trading with the EU-zone countries as well as other more developed countries or trading with nearby countries. In contrast, the CIA terms and $\mathrm{L} / \mathrm{C}$ terms are preferred to the $\mathrm{OA}$ and $\mathrm{CAD}$ when trading partners are located in lowincome countries or distant locations such as Asia, Africa and Middle East. Third, OA terms account for the largest share of Turkish exports across all industry groups. Fourth, the shares of inter-firm trade finance (particularly CIA) in Turkish exports dramatically increased over the period 2002-2012, while the shares of the intermediate trade finance (CAD and L/C) decreased substantially. These findings suggest that increased financial costs and tightened credit conditions induce Turkish exporters rely increasingly on inter-firm trade finance over time. Finally, the evidence show that Turkish exporters started to use CIA, the safest method of payment, more intensively than other methods during the crisis. This finding is not surprising given the fact that $\mathrm{L} / \mathrm{C}$ fees increased substantially because of the worldwide financial meltdown of 2008-2009.

Examining the use of financing terms in Turkey's imports, we first observe that the majority of import transactions take place under CIA terms, quite contrary to the results obtained with the export data. This finding supports the notion that Turkish importers have low bargaining power in dealing with foreign suppliers. Second, the results reveal that the share of inter-firm trade finance (OA and CIA) in imports is much larger than in exports, indicating that Turkish importers relied to larger extent on inter-firm trade finance compared to exports. Third, the results show that the CIA terms has been extensively used when Turkish importers deal with trading partners from high income countries or regions, suggesting that Turkish companies have low bargaining power in dealing with the sellers from advanced countries. Finally, despite being highly risky for importer, the share of CIA terms has increased even more over the years, making Turkish exporters even more vulnerable to payment risks. These patterns, taken together, suggest a shift away from bank intermediated trade finance (CAD and L/C) in imports to inter-firm trade finance, especially CIA. These findings show that importers in Turkey still

\footnotetext{
${ }^{28}$ See IMF-BAFT (2009) and Baldwin (2009).
} 
suffer from the financial constraints (the high cost and lack of finance to support import) caused by the financial crisis of 2008-2009. Overall, the patterns presented in this paper highlight the fact that Turkish traders have low bargaining power with their foreign partners in the selection of payment terms. Both exporters and importers are not able to set payment terms that are highly favorable to themselves and bear all risks associated with international trade transactions.

Though Turkey has achieved remarkable export growth over the past decade, it is still far from its full potential in terms of export values and export diversification (Türkcan, 2014). Beside lack of new orders and/or cancelled orders, a majority of firms in Turkey have cited lack of affordable trade finance as a major obstacle to export growth and this problem was made worse by the 2008-2009 financial crisis which forced banks offer fewer trade credits at higher costs (Acar, 2009; Malouche, 2009a). The findings from this study and some others (Acar, 2009; Malueche, 2009a; Demir, 2014) thus clearly demonstrate the importance of a wellfunctioning financial markets and financial intermediaries in Turkey, because to operate in foreign markets, Turkish firms need better access to trade finance. Accordingly, Turkey should take appropriate policy actions and measures to develop and maintain an effective financial system in order to broaden the range of trade finance instruments and risk mitigation tools at lower costs for new and small exporters who might have the potential to develop new export lines. Such developments would help Turkish firms not only access the finance they need to export more and diversify its exports in terms of products and destinations, but eliminate the risk of a trade transaction. Meanwhile, Turkey should establish institutional structures to ensure the efficient regulation and enforcement of contracts between exporters and importers, because stricter enforcement of contracts enhances Turkish firms' ability to increase their exports or enter markets and improve the survival of newly established bilateral trade relationship. Overall, a combination of these policies would help Turkey to diversify its product range and geographic scope, improve the quality of its exports, foster export growth, stabilize its export earnings, and thereby leading to sustainable long-run economic growth. 


\section{References}

Acar, O. (2009), "Evaluations for Trade and Trade Finance in Turkey”, TEPAV Policy Note, July.

Ahn, J. (2011), “A Theory of Domestic and International Trade Finance”, International Monetary Fund Working Papers No.11/262.

Ahn, J. (2013), "Estimating the Direct Impact of Bank Liquidity Shocks on the Real Economy: Evidence from Imports by Letters of Credit in Colombia", International Monetary Fund, mimeo.

Aldan, A. and O. Y. Çulha (2013), "The Role of Extensive Margin in Exports of Turkey: A Comparative Analysis", Central Bank of Turkey Working Paper No.13/32.

Amiti, M. and D. E. Weinstein (2011), "Exports and Financial Shocks", The Quarterly Journal of Economics, 126(4), 1841-1877. doi:10.1093/qje/qjir033

Antras, P. and C. F. Foley (2013), "Poultry in Motion: A Study of International Trade Finance Practices", Harward University, mimeo.

Asmundson, I., Dorsey, T., Khachatryan, A., Niculcea, I. and M. Saito (2011), “Trade and Trade Finance in the 2008-2009 Financial Crisis", International Monetary Fund, Washington, D.C., IMF Working Paper No.11/16.

Auboin, M. (2007), "Boosting Trade Finance in Developing Countries: What Link with the WTO?", WTO Staff Working Paper ERSD No. 2007-04.

Auboin, M. and M. Engemann (2013), "Trade Finance in Periods of Crisis: What Have We Learned in Recent Years?, WTO Staff Working Paper ERSD No.2013-01.

Baldwin, R. (2009), “The Great Trade Collapse: What Caused It and What Does It Mean?”, In: Richard Baldwin (Ed.), The Great Trade Collapse: Causes, Consequences and Prospects. London: Centre for Economic Policy Research (CEPR), p. 1-14.

Behrens, K., Corcos, G., and G. Mion (2013), "Trade Crisis? What Trade Crisis?", The Review of Economics and Statistics, 95(2), 702-709. doi:10.1162/REST_a_00287

BIS (Bank for International Settlements) (2014), "Trade Finance: Developments and Issues", Committee on the Global Financial System Papers No.50, Basel, Switzerland.

Bricongne, J-C., Fontagne, L., Gaulier, G., Taglioni, D., and V. Vicard (2012), "Firms and the Global Crisis: French Exports in Turmoil”, Journal of International Economics, 87 (1), 134-146. doi:10.1016/j.jinteco.2011.07.002

Chauffour, J.-P. and T. Farole (2009), “Trade Finance in Crisis: Market Adjustment or Market Failure?”, The World Bank Policy Research Working Paper Series No.5003.

Chor, D. and K. Manova (2012), "Off the Cliff and Back? Credit Conditions and International Trade during the Global Financial Crisis", Journal of International Economics, 87(1), 117-133. doi:10.1016/j.jinteco.2011.04.001

Contessi,S. and F. Nicola (2012), "What Do We Know about the Relationship between Access to Finance and International Trade?", Federal Reserve Bank of St. Louis Working Papers No. 2012-054.

Cunat, V. (2007), "Suppliers as Debt Collectors and Insurance Providers", Review of Financial Studies, 20, 491-527. doi:10.1093/rfs/hhl015 
Demir, B. (2014), “Trade Financing: Challenges for Developing-country Exporters", CESifo Forum 15 (3), 2014, 34-38.

Demir, B. and B. Javorcik (2014), "Grin and Bear It: Producer-financed Exports from an Emerging Market”, CEPR Discussion Paper No. DP10142.

Eck, K. (2012), "The Effect of Cash-In-Advance Financing on Exporting during the Recent Financial Crisis-Firm Level Evidence from Europe and Central Asia", Bavarian Graduate Program in Economics, mimeo.

Glady, N. and J. Potin (2011), "Bank Intermediation and Default Risk in International Trade-Theory and Evidence", ESSEC Business School Working Paper.

Gros, D. and C. Selçuki (2013), "The Changing Structure of Turkey's Trade and Industrial Competitiveness: Implications for the EU", Centre for European Policy Studies (CEPS) Working Paper Series No.03.

Hoefele, A., Schmidt-Eisenlohr, T. and Z. Yu (2013), "Payment Choice in International Trade: Theory and Evidence from Cross-Country Firm Level Data”, CESifo Working Paper No. 4350.

Iacovone, L. and Z. Zavacka (2009), "Banking Crises and Exports: Lessons from the Past?", The World Bank Policy Research Working Paper No.5016.

ICC (International Chamber of Commerce) (2009), "Rethinking Trade Finance 2009: An ICC Global Survey", Banking Commission Market Intelligence Report, ICC, Paris.

ICC (International Chamber of Commerce) (2010), "Rethinking Trade Finance 2010: An ICC Global Survey”, Banking Commission Market Intelligence Report, ICC, Paris.

IMF-BAFT (International Monetary Fund-Bankers' Association for Finance and Trade). (2009), "IMFBAFT Trade Finance Survey: A Survey among Banks Assessing the Current Trade Finance Environment", Report by FImetrix for IMF and BAFT, Washington, DC.

ITA (International Trade Administration) (2012), “Trade Finance Guide: A Quick Reference for U.S. Exporters", U.S. Department of Commerce, Washington, DC.

ITC (International Trade Centre) (2009), "How to Access to Trade Finance: A Guide for Exporting SMEs", Geneva, Switzerland.

Kaminski, B. and F. Ng (2006), "Turkey's Evolving Trade Integration into Pan-European Markets”, The World Bank Policy Research Working Paper Series No.3908.

Kalkan, S., Dündar, H.Ç. and A. Dinççağ (2010), "Trade and Trade Finance in Turkey: What is the Impact of the Finance Problems in the Decrease in Exports?", TEPAV Policy Note No. N201013.

Kalkan, S. and H.E. Cünedioğlu (2010), “Did Turkey’s Economy Recover from the Crisis? Did We OutCompete Rivals?”, TEPAV Policy Note No. N201029.

Levchenko, A. A., Lewis, L. T. and L. L. Tesar (2010), "The Collapse of International Trade during the 2008-2009 Crisis: In Search of the Smoking Gun”, NBER Working Papers No.16006.

Love, I. (2013), "Role of Trade Finance”, In: Gerard Caprio (Ed.), The Evidence and Impact of Financial Globalization, Oxford: Elsevier Inc., 199-212. doi:10.1016/B978-0-12-397874-5.00029-4

Malouche, M. (2009a), "Trade and Trade Finance Developments in 14 Developing Countries Post September 2008”, World Bank Policy Research Working Paper No.5138. 
Malouche, M. (2009b), "World Bank Firm and Bank Surveys in 14 Developing Countries, 2009 and 2010", In: Jean-Pierre Chauffour and Mariem Malaouche (Ed.), Trade Finance during the Great Trade Collapse. World Bank, Washington, DC, 173-199.

Manova, K. (2013), "Credit Constraints, Heterogeneous Firms and International Trade", National Bureau of Economic Research Working Paper No. 14531.

Menichini, A. M. (2009), "Inter-Firm Trade Finance in Times of Crisis", The World Bank Policy Research Working Paper Series No.5112.

Mora, J., and W. Powers (2011), "Global Perspectives in the Decline of Trade Finance”, In: Jean-Pierre Chauffour and Mariem Malaouche (Ed.), Trade Finance during the Great Trade Collapse. World Bank, Washington, DC, 117-133.

Niepmann, F. and T. Schmidt-Eisenlohr (2013), "International Trade, Risk and Role of Banks", Federal Reserve Bank of New York Staff Reports No.633.

Olsen, M. (2013), "How Firms Overcome Weak International Contract Enforcement: Repeated Interaction, Collective Punishment and Trade Finance", University of Navarra, IESE Business School, mimeo.

Paravisini, D., Rappoport, V., Schnabl, P. and D. Wolfenzon (2011), "Dissecting the Effect of Credit Supply on Trade: Evidence from Matched Credit-Export Data", NBER Working Papers No.16975.

Saygil1, H. and M. Saygilı (2011), "Structural Changes in Exports of an Emerging Economy: Case of Turkey", Structural Change and Economic Dynamics, 22, 342-360. doi:10.1016/j.strueco.2011.08.001

Schmidt-Eisenlohr, T. (2013), "Towards a Theory of Trade Finance", Journal of International Economics, 91(1), 96-112. doi:10.1016/j.jinteco.2013.04.005

Türkcan, K. (2014), “Investigating The Role of Extensive Margin, Intensive Margin, Price and Quantity Components on Turkey's Export Growth during 1998-2011", Turkish Economic Association Discussion Paper No.2014/2. 


\section{APPENDIX A}

Table A1: Methods of Payment in International Transactions and the Risk for Traders

\begin{tabular}{|c|c|c|c|c|c|}
\hline $\begin{array}{l}\text { Method } \\
\text { Payment }\end{array}$ & Definition & Applicability & Risk & Pros & Cons \\
\hline $\begin{array}{l}\text { Cash-in } \\
\text { advance }\end{array}$ & $\begin{array}{l}\text { Payment prior } \\
\text { to the transfer } \\
\text { of ownership of } \\
\text { the goods }\end{array}$ & $\begin{array}{l}\text { Recommended } \\
\text { for use in high- } \\
\text { risk trade } \\
\text { relationships or } \\
\text { export markets, } \\
\text { and appropriate } \\
\text { for small export } \\
\text { transactions }\end{array}$ & $\begin{array}{l}\text { Exporter is } \\
\text { exposed to } \\
\text { virtually no risk } \\
\text { as the burden } \\
\text { of risk is placed } \\
\text { almost } \\
\text { completely on } \\
\text { the importer }\end{array}$ & $\begin{array}{l}\text { *Payment } \\
\text { before shipment } \\
\text { *Eliminates risk } \\
\text { of non-payment }\end{array}$ & $\begin{array}{l}\text { *May lose } \\
\text { customers to } \\
\text { competitors } \\
\text { over payment } \\
\text { terms } \\
\text { *No additional } \\
\text { earnings } \\
\text { through } \\
\text { financing } \\
\text { operations }\end{array}$ \\
\hline Letter of credit & $\begin{array}{l}\text { A commitment } \\
\text { by a bank on } \\
\text { the behalf of } \\
\text { the importer } \\
\text { that payment } \\
\text { will be made to } \\
\text { the beneficiary } \\
\text { (exporter) } \\
\text { provided that } \\
\text { the terms and } \\
\text { conditions } \\
\text { stated in the } \\
\text { L/C have been } \\
\text { met }\end{array}$ & $\begin{array}{l}\text { Recommended } \\
\text { for use in } \\
\text { higher-risk } \\
\text { situations or } \\
\text { new or less- } \\
\text { established } \\
\text { trade } \\
\text { relationships } \\
\text { when the } \\
\text { exporter is } \\
\text { satisfied with } \\
\text { the } \\
\text { creditworthiness } \\
\text { of the } \\
\text { importer's bank }\end{array}$ & $\begin{array}{l}\text { Risk is spread } \\
\text { between } \\
\text { exporter and } \\
\text { importer, } \\
\text { provided that } \\
\text { all terms and } \\
\text { conditions } \\
\text { specified in the } \\
\text { L/C are } \\
\text { adhered to }\end{array}$ & $\begin{array}{l}\text { *Payment made } \\
\text { after shipment } \\
* \text { A variety of } \\
\text { payment, } \\
\text { financing and } \\
\text { risk mitigation } \\
\text { options } \\
\text { available }\end{array}$ & $\begin{array}{l}\text { *Labor } \\
\text { intensive } \\
\text { process } \\
\text { *Relatively } \\
\text { expensive } \\
\text { method in } \\
\text { terms of } \\
\text { transaction } \\
\text { costs }\end{array}$ \\
\hline $\begin{array}{l}\text { Cash against } \\
\text { documents }\end{array}$ & $\begin{array}{l}\text { Exporter } \\
\text { entrusts the } \\
\text { collection of } \\
\text { payment to the } \\
\text { exporter's } \\
\text { bank, which } \\
\text { sends } \\
\text { documents to } \\
\text { the importer's } \\
\text { bank, along } \\
\text { with } \\
\text { instructions for } \\
\text { payment. }\end{array}$ & $\begin{array}{l}\text { Recommended } \\
\text { for use in } \\
\text { established } \\
\text { trade } \\
\text { relationships, in } \\
\text { stable export } \\
\text { markets and for } \\
\text { transactions } \\
\text { involving ocean } \\
\text { shipments }\end{array}$ & $\begin{array}{l}\text { Riskier for the } \\
\text { exporter, } \\
\text { though CAD } \\
\text { terms are more } \\
\text { convenient and } \\
\text { cheaper than an } \\
\text { L/C to the } \\
\text { importer }\end{array}$ & $\begin{array}{l}\text { *Bank } \\
\text { assistance in } \\
\text { obtaining } \\
\text { payment } \\
\text { *The process is } \\
\text { simple, fast and } \\
\text { less costly than } \\
\text { L/C }\end{array}$ & $\begin{array}{l}\text { *Banks' role is } \\
\text { limited and } \\
\text { they do not } \\
\text { guarantee } \\
\text { payment } \\
\text { *Banks do not } \\
\text { verify the } \\
\text { accuracy of the } \\
\text { documents }\end{array}$ \\
\hline Open account & $\begin{array}{l}\text { The goods are } \\
\text { shipped and } \\
\text { delivered } \\
\text { before payment } \\
\text { is due, which is } \\
\text { typically in } 30 \text {, } \\
60 \text { or } 90 \text { days }\end{array}$ & $\begin{array}{l}\text { Recommended } \\
\text { for use in (a) } \\
\text { low-risk trading } \\
\text { relationships or } \\
\text { markets and (b) } \\
\text { in competitive } \\
\text { markets to win } \\
\text { customers with } \\
\text { the use of one } \\
\text { or more } \\
\text { appropriate } \\
\text { trade finance } \\
\text { techniques. }\end{array}$ & $\begin{array}{l}\text { Substantial risk } \\
\text { to the exporter } \\
\text { because the } \\
\text { buyer could } \\
\text { default on } \\
\text { payment } \\
\text { obligation after } \\
\text { shipment of the } \\
\text { goods }\end{array}$ & $\begin{array}{l}\text { *Boost } \\
\text { competitiveness } \\
\text { in the global } \\
\text { market } \\
\text { *Help establish } \\
\text { and maintain a } \\
\text { successful trade } \\
\text { relationship }\end{array}$ & $\begin{array}{l}\text { *Significant } \\
\text { exposure to the } \\
\text { risk of non- } \\
\text { payment } \\
\text { *Additional } \\
\text { costs associated } \\
\text { with risk } \\
\text { mitigation } \\
\text { measures }\end{array}$ \\
\hline
\end{tabular}

Source: ITA, 2012 
Table A2: Structure and classification of Turkey's trade finance data by methods of payments, 2002-2012

\begin{tabular}{|c|c|c|c|c|c|c|c|c|c|c|c|}
\hline Methods of Payments & 2002 & 2003 & 2004 & 2005 & 2006 & 2007 & 2008 & 2009 & 2010 & 2011 & 2012 \\
\hline $\begin{array}{l}\text { Cash against Goods, Cash on } \\
\text { Delivery }\end{array}$ & $\checkmark 1$ & $\checkmark 1$ & $\checkmark 1$ & $\checkmark 1$ & $\checkmark 1$ & $\checkmark 1$ & $\checkmark 1$ & $\checkmark 1$ & $\checkmark 1$ & $\checkmark 1$ & $\checkmark 1$ \\
\hline Advanced Payment & $\sqrt{ } 2$ & $\sqrt{ } 2$ & $\sqrt{ } 2$ & $\sqrt{2}$ & $\sqrt{ } 2$ & $\sqrt{2}$ & $\sqrt{ } 2$ & $\sqrt{2}$ & $\sqrt{2}$ & $\sqrt{ } 2$ & $\sqrt{2}$ \\
\hline Cash Against Documents & $\sqrt{3}$ & $\sqrt{3}$ & $\sqrt{3}$ & $\sqrt{3}$ & $\sqrt{3}$ & $\sqrt{3}$ & $\sqrt{3}$ & $\sqrt{3}$ & $\sqrt{3}$ & $\sqrt{3}$ & $\sqrt{3}$ \\
\hline By Acceptance Credit & $\checkmark 5$ & $\sqrt{5}$ & $\sqrt{5}$ & $\sqrt{5}$ & $\sqrt{5}$ & $\sqrt{5}$ & & & & & \\
\hline Advanced Letter of Credit & $\sqrt{4}$ & $\sqrt{4}$ & $\sqrt{4}$ & $\sqrt{4}$ & $\sqrt{ } 4$ & $\sqrt{ } 4$ & $\sqrt{4}$ & $\sqrt{4}$ & & & \\
\hline $\begin{array}{l}\text { Letter of Credit Payable at a } \\
\text { Specified Future Date }\end{array}$ & $\checkmark 4$ & $\sqrt{4}$ & $\sqrt{4}$ & $\sqrt{4}$ & $\sqrt{ } 4$ & $\sqrt{ } 4$ & $\sqrt{4}$ & $\sqrt{ } 4$ & $\checkmark 4$ & $\checkmark 4$ & $\checkmark 4$ \\
\hline Without Waiver & $\sqrt{5}$ & $\sqrt{5}$ & $\checkmark 5$ & $\sqrt{5}$ & $\sqrt{ } 5$ & $\sqrt{ } 5$ & $\sqrt{5}$ & $\sqrt{5}$ & $\sqrt{5}$ & $\checkmark 5$ & $\sqrt{5}$ \\
\hline Payment Type Uncertain & $\sqrt{5}$ & $\sqrt{5}$ & $\sqrt{5}$ & $\sqrt{5}$ & $\sqrt{5}$ & $\sqrt{5}$ & $\sqrt{5}$ & $\sqrt{5}$ & & & \\
\hline $\begin{array}{l}\text { Type of Payment with Abroad } \\
\text { Credit(Public) }\end{array}$ & $\sqrt{5}$ & $\sqrt{5}$ & $\sqrt{5}$ & $\sqrt{5}$ & $\sqrt{5}$ & $\sqrt{5}$ & & & & & \\
\hline Account of Barter & $\sqrt{5}$ & $\sqrt{5}$ & $\checkmark 5$ & $\sqrt{5}$ & $\sqrt{5}$ & $\sqrt{5}$ & & & & & \\
\hline Private Barter & $\sqrt{5}$ & $\sqrt{5}$ & $\checkmark 5$ & $\sqrt{5}$ & $\sqrt{ } 5$ & $\sqrt{ } 5$ & $\sqrt{5}$ & $\sqrt{5}$ & $\sqrt{5}$ & $\checkmark 5$ & $\checkmark 5$ \\
\hline Letter of Credit & & & $\sqrt{ } 4$ & $\checkmark 4$ & $\sqrt{ } 4$ & $\sqrt{ } 4$ & $\sqrt{4}$ & $\checkmark 4$ & $\checkmark 4$ & $\checkmark 4$ & $\checkmark 4$ \\
\hline Counter purchase & & & $\checkmark 5$ & $\sqrt{5}$ & $\sqrt{5}$ & $\sqrt{5}$ & $\sqrt{5}$ & $\sqrt{5}$ & $\sqrt{5}$ & $\checkmark 5$ & $\checkmark 5$ \\
\hline $\begin{array}{l}\text { Letter of Credit with Acceptance } \\
\text { Credit }\end{array}$ & & & $\checkmark 5$ & $\sqrt{ } 5$ & $\sqrt{5}$ & $\sqrt{5}$ & $\sqrt{5}$ & $\sqrt{5}$ & $\sqrt{ } 5$ & $\sqrt{5}$ & $\sqrt{5}$ \\
\hline $\begin{array}{l}\text { Documents with Acceptance } \\
\text { Credit }\end{array}$ & & & $\checkmark 5$ & $\sqrt{ } 5$ & $\sqrt{ } 5$ & $\checkmark 5$ & $\sqrt{ } 5$ & $\checkmark 5$ & $\checkmark 5$ & $\checkmark 5$ & $\sqrt{ } 5$ \\
\hline Goods with Acceptance Credit & & & $\checkmark 5$ & $\sqrt{5}$ & $\sqrt{5}$ & $\sqrt{5}$ & $\sqrt{5}$ & $\sqrt{5}$ & $\checkmark 5$ & $\sqrt{5}$ & $\sqrt{5}$ \\
\hline Private Account & & & & & & $\checkmark 5$ & $\sqrt{5}$ & $\sqrt{5}$ & $\sqrt{5}$ & $\checkmark 5$ & $\checkmark 5$ \\
\hline
\end{tabular}

Notes: Many different types of payment methods exist in the database and types vary greatly from year to year. A check mark $(\checkmark)$ means that international transactions recorded under this type of payment are available in that year. In order to make consistent analysis from year to year, these are grouped into five main categories: open account (1), cash-in advance (2), cash against documents (3), letter of credit (4) and other (5).

Source: TURKSTAT 
Table A3: List of countries and geographical composition of each region

\begin{tabular}{|c|c|c|c|c|}
\hline Africa & Tunisia ${ }^{\mathrm{C}}$ & Saint Lucia ${ }^{\mathrm{C}}$ & Niue $^{\mathrm{C}}$ & Malta $^{\mathrm{D}}$ \\
\hline$\overline{\text { Algeria }} \mathrm{C}$ & Uganda $^{\mathrm{A}}$ & St. Pierre\& Miquelon ${ }^{\mathrm{C}}$ & No.Mariana Isds. ${ }^{\text {D }}$ & Netherlands ${ }^{\mathrm{D}}$ \\
\hline Angolac & Egypt $^{\mathrm{B}}$ & St. Vincent\&Grenadines ${ }^{C}$ & Marshall Isds ${ }^{C}$ & Norway ${ }^{\mathrm{D}}$ \\
\hline Burundi ${ }^{\mathrm{A}}$ & Tanzania $^{\mathrm{A}}$ & Suriname $\mathrm{C}^{\mathrm{C}}$ & Palau ${ }^{\mathrm{C}}$ & Poland ${ }^{\mathrm{D}}$ \\
\hline Cameroon $^{\mathrm{B}}$ & Burkina Faso $^{\mathrm{A}}$ & Trinidad and Tobago ${ }^{\mathrm{D}}$ & Pakistan $^{\mathrm{B}}$ & Portugal $^{\mathrm{D}}$ \\
\hline Cape Verde ${ }^{B}$ & Zambia $^{\mathrm{B}}$ & Turks\&Caicos Isds. ${ }^{\mathrm{D}}$ & Papua N. Guinea ${ }^{\mathrm{B}}$ & Romania $^{\mathrm{C}}$ \\
\hline Central Afr. Rep. ${ }^{\mathrm{A}}$ & America & $\mathrm{USA}^{\mathrm{D}}$ & Philippines $^{\mathrm{B}}$ & San Marino $^{\mathrm{D}}$ \\
\hline Chad $^{\mathrm{A}}$ & Antigua\& Barbuda ${ }^{\mathrm{D}}$ & Uruguay $^{\mathrm{D}}$ & Pitcairn ${ }^{\mathrm{D}}$ & Slovak Rep. ${ }^{\mathrm{D}}$ \\
\hline Comoros $^{\mathrm{A}}$ & Argentina ${ }^{\mathrm{C}}$ & Venezuelac & Timor-Leste $^{B}$ & Slovenia $^{\mathrm{D}}$ \\
\hline Congo $^{\mathrm{B}}$ & Bahamas $^{\mathrm{D}}$ & Br. Virgin Isds. ${ }^{D}$ & India $^{B}$ & Spain $^{\mathrm{D}}$ \\
\hline Congo Dem. Rep. ${ }^{\mathrm{A}}$ & Barbados $^{\mathrm{D}}$ & Asia & Singapore ${ }^{\mathrm{D}}$ & Sweden ${ }^{\mathrm{D}}$ \\
\hline Benin $^{A}$ & Bermuda $^{\mathrm{D}}$ & Afghanistan ${ }^{\mathrm{A}}$ & Viet $\operatorname{Nam}^{\mathrm{B}}$ & Switzerland ${ }^{\mathrm{D}}$ \\
\hline Equatorial Guinea $^{\mathrm{D}}$ & Bolivia $^{\mathrm{A}}$ & American Samoa ${ }^{\mathrm{D}}$ & Thailand $^{C}$ & $\mathrm{UK}^{\mathrm{D}}$ \\
\hline Ethiopia $^{\mathrm{A}}$ & Brazil $^{\mathrm{C}}$ & Australia ${ }^{\mathrm{D}}$ & Tokelau $^{\mathrm{B}}$ & Middle East \\
\hline Eritrea $^{\mathrm{A}}$ & Belize $^{\mathrm{C}}$ & Bangladesh ${ }^{\mathrm{A}}$ & Tonga $^{\mathrm{B}}$ & Bahrain ${ }^{\mathrm{D}}$ \\
\hline Djibouti $^{B}$ & Canada $^{\mathrm{D}}$ & Bhutan $^{\mathrm{A}}$ & Tuvalu ${ }^{\mathrm{B}}$ & Palestine $^{\mathrm{B}}$ \\
\hline Gabon ${ }^{\mathrm{C}}$ & Cayman Isds. ${ }^{\mathrm{D}}$ & Solomon Isds. ${ }^{\mathrm{B}}$ & Wallis\& Futuna ${ }^{\mathrm{B}}$ & $\operatorname{Iran}^{\mathrm{C}}$ \\
\hline Gambia $^{\mathrm{A}}$ & Chile $^{\mathrm{D}}$ & Brunei $^{\mathrm{D}}$ & Samoa $^{\mathrm{B}}$ & Iraq $^{C}$ \\
\hline Ghana $^{\mathrm{B}}$ & Colombia $^{\mathrm{C}}$ & Myanmar ${ }^{\mathrm{A}}$ & Europe & Israel $^{\mathrm{D}}$ \\
\hline Guinea $^{\mathrm{A}}$ & Costa Rica ${ }^{\mathrm{C}}$ & Cambodia $^{\mathrm{A}}$ & $\overline{\text { Albania }} \mathrm{C}$ & Jordan $^{\mathrm{C}}$ \\
\hline Côte d'Ivoire ${ }^{B}$ & $\mathrm{Cuba}^{\mathrm{C}}$ & Sri Lanka ${ }^{B}$ & Andorra $^{\mathrm{D}}$ & Kuwait $^{\mathrm{D}}$ \\
\hline Kenya $^{\mathrm{A}}$ & Dominica $^{\mathrm{C}}$ & China $^{\mathrm{C}}$ & Austria ${ }^{\mathrm{D}}$ & Lebanon $^{\mathrm{C}}$ \\
\hline Liberia $^{\mathrm{A}}$ & Dominican Republic ${ }^{\mathrm{C}}$ & Christmas Isds. & Belgium $^{\mathrm{D}}$ & $\operatorname{Oman}^{\mathrm{D}}$ \\
\hline Libya $^{\mathrm{C}}$ & Ecuador ${ }^{\mathrm{C}}$ & Cook Isds. ${ }^{\mathrm{D}}$ & Bosnia\&Herzeg. ${ }^{\mathrm{C}}$ & Qatar ${ }^{\mathrm{D}}$ \\
\hline Madagascar ${ }^{\mathrm{A}}$ & El Salvador ${ }^{\mathrm{B}}$ & FijiC & Bulgaria ${ }^{C}$ & Saudi Arabia ${ }^{D}$ \\
\hline Malawi $^{\mathrm{A}}$ & Falkland Isds. $^{\mathrm{D}}$ & French Polynesia $^{\mathrm{D}}$ & Croatia $^{\mathrm{D}}$ & Syria ${ }^{B}$ \\
\hline Mali $^{\mathrm{A}}$ & So. Geo\& So. Sand. Isds. ${ }^{D}$ & Kiribati $^{\mathrm{B}}$ & Cyprus $^{\mathrm{D}}$ & $\mathrm{UAE}^{\mathrm{D}}$ \\
\hline Mauritania $^{\mathrm{B}}$ & Grenada $^{\mathrm{C}}$ & Guam $^{\mathrm{D}}$ & Czech Rep. ${ }^{\mathrm{D}}$ & Yemen $^{\mathrm{B}}$ \\
\hline Mauritius ${ }^{\mathrm{C}}$ & Guatemala $^{\mathrm{B}}$ & Hong Kong ${ }^{\mathrm{D}}$ & Denmark $^{\mathrm{D}}$ & CIS \\
\hline Morocco $^{\mathrm{B}}$ & Guyana $^{\mathrm{B}}$ & Indonesia ${ }^{\mathrm{B}}$ & Estonia $^{\mathrm{D}}$ & $\overline{\text { Azerbaijan }}{ }^{\mathrm{C}}$ \\
\hline Mozambique $^{\mathrm{A}}$ & Haiti $^{\mathrm{A}}$ & Japan $^{\mathrm{D}}$ & Finland ${ }^{\mathrm{D}}$ & Armenia $^{\mathrm{B}}$ \\
\hline Niger $^{A}$ & Honduras $^{\mathrm{B}}$ & North Korea ${ }^{\mathrm{B}}$ & France $^{\mathrm{D}}$ & Belarus ${ }^{C}$ \\
\hline Nigeria $^{B}$ & Jamaica $^{\mathrm{C}}$ & South Korea ${ }^{\mathrm{D}}$ & Germany $^{\mathrm{D}}$ & Georgia $^{\mathrm{B}}$ \\
\hline Guinea-Bissau $^{\mathrm{A}}$ & Mexico $^{\mathrm{C}}$ & $\operatorname{Laos}^{\mathrm{B}}$ & Gibraltar $^{\mathrm{D}}$ & Kazakhstan ${ }^{\mathrm{C}}$ \\
\hline Rwanda ${ }^{\mathrm{A}}$ & Montserrat ${ }^{\mathrm{B}}$ & $\mathrm{Macao}^{\mathrm{D}}$ & Greece $^{\mathrm{D}}$ & Kyrgyz Republic ${ }^{A}$ \\
\hline Saint Helena ${ }^{B}$ & Neth. Antilles ${ }^{\mathrm{D}}$ & Malaysia ${ }^{\mathrm{C}}$ & Greenland ${ }^{\mathrm{D}}$ & Moldova $^{\mathrm{B}}$ \\
\hline Sao Tome \&Principe ${ }^{B}$ & Aruba $^{\mathrm{D}}$ & Maldives $^{\mathrm{C}}$ & Hungary $\mathrm{C}$ & Russia $^{\mathrm{D}}$ \\
\hline Senegal ${ }^{\mathrm{B}}$ & Nicaragua $^{B}$ & Mongolia $^{\mathrm{B}}$ & Iceland $\mathrm{d}^{\mathrm{D}}$ & Tajikistan $^{\mathrm{A}}$ \\
\hline Seychelles ${ }^{\mathrm{C}}$ & PanamaC & Nauru $^{\mathrm{C}}$ & Ireland ${ }^{\mathrm{D}}$ & Turkmenistan ${ }^{\mathrm{C}}$ \\
\hline Sierra Leone ${ }^{\mathrm{A}}$ & Paraguay $^{\mathrm{B}}$ & $\mathrm{Nepal}^{\mathrm{A}}$ & Italy ${ }^{\mathrm{D}}$ & Ukraine $^{B}$ \\
\hline Somalia $^{\mathrm{A}}$ & PeruC & New Caledonia ${ }^{\mathrm{D}}$ & Latvia $^{\mathrm{D}}$ & Uzbekistan $^{\mathrm{B}}$ \\
\hline Zimbabwe $^{\mathrm{A}}$ & Saint Kitts\& Nevis ${ }^{\mathrm{D}}$ & Vanuatu $^{\mathrm{B}}$ & Lithuania $^{\mathrm{D}}$ & \\
\hline $\operatorname{Tog}^{A}$ & Anguilla ${ }^{\mathrm{C}}$ & New Zealand ${ }^{\mathrm{D}}$ & Luxembourg $^{\mathrm{D}}$ & \\
\hline
\end{tabular}

Notes: The country composition of regions is based on the World Trade Organization's analytical regions. CIS stands for Commonwealth of Independent States. Using the World Bank classification system, 206 countries are also categorized into four different groups: LI=Low Income (A); LMI=Lower Middle Income (B); UMI=Upper Middle Income (C); HI=High Income (D). 